Article

\title{
Sulfide Breccias from the Semenov-3 Hydrothermal Field, Mid-Atlantic Ridge: Authigenic Mineral Formation and Trace Element Pattern
}

\author{
Irina Melekestseva ${ }^{1, *}$, Valery V. Maslennikov ${ }^{1,2}$, Nataliya P. Safina ${ }^{1,2}$, Paolo Nimis ${ }^{3}$ (D), \\ Svetlana Maslennikova ${ }^{1}$, Victor Beltenev ${ }^{4}$, Irina Rozhdestvenskaya ${ }^{4}$, Leonid Danyushevsky ${ }^{5}$ (D), \\ Ross Large ${ }^{4}$, Dmitry Artemyev ${ }^{1}$, Vasily Kotlyarov ${ }^{1}$ and Luca Toffolo ${ }^{3}$ \\ 1 Institute of Mineralogy, Urals Branch of Russian Academy of Sciences, Chelyabinsk District, Miass 456317, \\ Russia; maslennikov@mineralogy.ru (V.V.M.); natali.safina2015@yandex.ru (N.P.S.); \\ svmas@mineralogy.ru (S.M.); artemyev@mineralogy.ru (D.A.); kotlyarov@mineralogy.ru (V.K.) \\ 2 Faculty of Geology, South-Urals State University, 8 Iyulya st. 10, Chelyabinsk District, Miass 456301, Russia \\ 3 Dipartimento di Geoscienze, Università degli Studi di Padova, Via Gradenigo 6, 35131 Padova, Italy; \\ paolo.nimis@unipd.it (P.N.); luca.toffolo@unipd.it (L.T.) \\ 4 Polar Marine Geosurvey Expedition, Pobedy st. 24, Lomonosov, St. Petersburg 198412, Russia; \\ v.belt@yandex.ru (V.B.); woody2510@yandex.ru (I.R.); ross.large@utas.edu.au (R.L.) \\ 5 CODES ARC Centre of Excellence in Ore Deposits, University of Tasmania, Private Bag 51, Hobart, \\ TAS 7001, Australia; 1.dan@utas.edu.au \\ * Correspondence: melekestseva-irina@yandex.ru; Tel.: +7-950-7447-301
}

Received: 14 May 2018; Accepted: 23 July 2018; Published: 27 July 2018

Abstract: The aim of this paper is the investigation of the role of diagenesis in the transformation of clastic sulfide sediments such as sulfide breccias from the Semenov-3 hydrothermal field (Mid-Atlantic Ridge). The breccias are composed of marcasite-pyrite clasts enclosed in a barite-sulfide-quartz matrix. Primary hydrothermal sulfides occur as colloform, fine-crystalline, porous and radial marcasite-pyrite clasts with inclusions or individual clasts of chalcopyrite, sphalerite, pyrrhotite, bornite, barite and rock-forming minerals. Diagenetic processes are responsible for the formation of more diverse authigenic mineralization including framboidal, ovoidal and nodular pyrite, coarse-crystalline pyrite and marcasite, anhedral and reniform chalcopyrite, inclusions of $\mathrm{HgS}$ phase and pyrrhotite-sphalerite-chalcopyrite aggregates in coarse-crystalline pyrite, zoned bornite-chalcopyrite grains, specular and globular hematite, tabular barite and quartz. The early diagenetic ovoid pyrite is enriched in most trace elements in contrast to late diagenetic varieties. Authigenic lower-temperature chalcopyrite is depleted in trace elements relative to high-temperature hydrothermal ones. Trace elements have different modes of occurrence: Se is hosted in pyrite and chalcopyrite; $\mathrm{Tl}$ is related to sphalerite and galena nanoinclusions; $\mathrm{Au}$ is associated with galena; As in pyrite is lattice-bound, whereas in chalcopyrite it is related to tetrahedrite-tennantite nanoinclusions; $\mathrm{Cd}$ in pyrite is hosted in sphalerite inclusions; $\mathrm{Cd}$ in chalcopyrite forms its own mineral; $\mathrm{Co}$ and $\mathrm{Ni}$ are hosted in chalcopyrite.

Keywords: authigenesis; diagenesis; LA-ICP-MS; sulfide hydrothermal fields; Mid-Atlantic Ridge; sulfide breccias; trace elements

\section{Introduction}

Over the recent decades, great progress has been achieved in understanding trace element behavior in sulfide minerals from oceanic hydrothermal fields [1-8]. One of the reasons has been the development of laser ablation inductively coupled plasma mass spectrometry (LA-ICP-MS) and its 
application in mineral geochemistry [1-10]. Most studies of oceanic hydrothermal fields concern the geochemistry of sulfides from smoker chimneys, diffusers, and massive or colloform ores, which are the result of medium- to high-temperature hydrothermal processes. Little attention, however, has been paid to the study of the products of erosion of massive sulfide bodies (clastic sulfide sediments), although some massive sulfide bodies host significant amounts of clastic sulfides, e.g., Bent Hill, Middle Valley of the North Juan de Fuca Ridge [11]. Fossil volcanic-hosted massive sulfide (VHMS) deposits may completely be composed of clastic layers produced by vigorous erosion of massive sulfide mounds [12-16]. The lithified clastic sulfides mostly consist of fragments of hydrothermal sulfides from chimneys, diffusers, massive, colloform and stringer-disseminated sulfides, which underwent diagenetic alteration with formation of new (i.e., authigenic, cf. [17]) mineral assemblages and redistribution (remobilization) of valuable components between primary hydrothermal and authigenic minerals. Of special interest are authigenic sulfide nodules, because they exhibit zonal morphological and geochemical structures related to the trace elements in the course of diagenesis [18,19].

Another key point of seafloor hydrothermal sulfide fields is their possible future mining. Concern about environmental hazards (even for exploration of inactive hydrothermal fields) and the relatively small sizes, tonnages and grades of seafloor sulfide bodies compared to many on-land VHMS deposits [9,20-23] have generated skepticism about the real mining potential of marine resources, although first steps have already been made to approach their possible exploitation $[24,25]$. In seafloor hydrothermal sites, the valuable base and precious metals are mostly contained in $\mathrm{Cu}-(\mathrm{Fe})$ (chalcopyrite, isocubanite, covellite and related minerals) and $\mathrm{Zn}$ (sphalerite, wurtzite) sulfides, but Fe sulfides make up a significant part of both seafloor and subseafloor ores [4,10,26-37]. This circumstance should be taken into account during seafloor mining and extraction of valuable components, since pyrite can host up to a few percents of $\mathrm{Cu}$ and $\mathrm{Zn}$, as well as noticeable contents of As, $\mathrm{Co}, \mathrm{Ni}, \mathrm{Se}, \mathrm{Hg}$, etc. (see review in [9]).

The aim of this paper is the investigating of the role of diagenesis in the transformation of clastic sulfide sediments such as pyrite-rich sulfide breccias from the Semenov-3 hydrothermal field (Mid-Atlantic Ridge). We will illustrate that diagenetic processes are responsible for (i) the formation of more diverse authigenic mineralization relative to primary hydrothermal massive sulfides and (ii) morphological and geochemical differences between primary hydrothermal and authigenic sulfides. The detailed examination of sulfide breccias from the Semenov-3 hydrothermal field allowed prediction of the presence of $\mathrm{Cu}$-rich massive sulfides in this area and identification of different mode of occurrence of trace elements in pyrite, marcasite and chalcopyrite.

\section{Geological Background}

The Semenov-3 hydrothermal sulfide field is part of a giant eponymous hydrothermal sulfide cluster located at $13^{\circ} 30^{\prime} \mathrm{N}$ on the Mid-Atlantic Ridge, which was discovered in 2007 during the 30th cruise of the Russian research vessel Professor Logatchev by the Polar Marine Geosurvey Expedition (PMGE) jointly with VNIIOkeangeologiya [38]. The cluster consists of four inactive (1, 3, 4 and 5) and one active (2) hydrothermal fields with possible massive sulfide resources estimated at $40 \mathrm{Mt}$ [35]. The Semenov cluster is located between the Fifteen Twenty and Marathon transform fracture zones on the western wall of the Mid-Atlantic Ridge (MAR), on an EW-trending seamount $10 \mathrm{~km}$-long and $4.5 \mathrm{~km}$-wide (Figure 1) [38]. This seamount is an oceanic core complex (OCC), which comprises a smooth, corrugated and striated dome with a rougher western part [39]. Serpentinized ultramafic rocks, fresh and moderately hydrothermally altered pillow basalts, dolerites, gabbros, tonalites, diorites, plagiogranites, as well as talcites, talc-chlorite rocks and amphibolites were recovered from the OCC surface [38-41].

The Semenov-3 field $\left(13^{\circ} 30.70^{\prime} \mathrm{N}, 44^{\circ} 55.00^{\prime} \mathrm{W}\right)$ is located on the northeastern slope of the seamount at depths of $2400-2600 \mathrm{~m}$ and is associated with altered basalts (Figure 1). Sulfide breccias containing marcasite-pyrite clasts enclosed by a sulfide-quartz matrix, with numerous fractures and cavities encrusted with barite crystals, were recovered from the seafloor in 2007, while massive sulfides 
dominated by pyrite and marcasite were dredged in $2009[38,40]$. The ${ }^{230} \mathrm{Th} /{ }^{234} \mathrm{U}$ age of sulfide samples dredged in 2007 ranges from 35.5 to 90.3 thousand years [42].

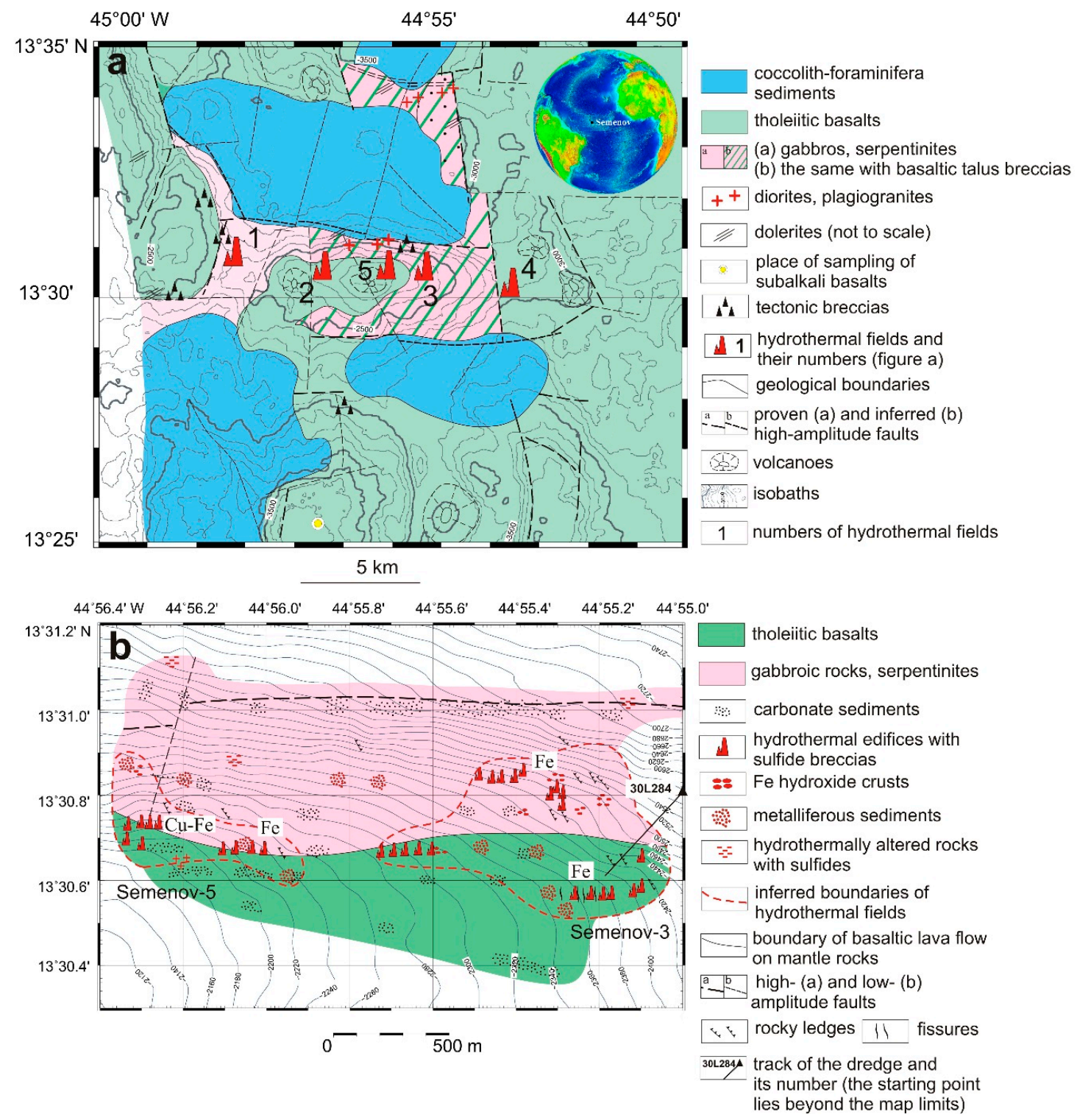

Figure 1. Geological scheme of the Semenov hydrothermal cluster in the Central Atlantic (a) and Semenov-3 hydrothermal field (b), simplified after unpublished PMGE open-file reports $(2007,2009)$.

\section{Samples and Analytical Techniques}

Sulfide breccias from the Semenov-3 hydrothermal field were collected during the 30th cruise of the research vessel Professor Logachev using dredge station 30L284 (hereafter, st. 284) (Table 1). Nine hand specimens were studied macroscopically on-board and twenty polished sections were studied by reflected light at the Institute of Mineralogy (IMin UB RAS), Miass (Russia).

Table 1. Coordinates of the dredge station 284 at the Semenov-3 hydrothermal field.

\begin{tabular}{cccccc}
\hline \multicolumn{2}{c}{ Latitude } & \multicolumn{2}{c}{ Longitude } & \multicolumn{2}{c}{ Depth } \\
\hline Start & Finish & Start & Finish & Start & Finish \\
\hline $13^{\circ} 30.801^{\prime}$ & $13^{\circ} 30.601^{\prime} \mathrm{N}$ & $44^{\circ} 54.800^{\prime} \mathrm{W}$ & $44^{\circ} 55.195^{\prime} \mathrm{W}$ & $2616 \mathrm{~m}$ & $2393 \mathrm{~m}$ \\
\hline
\end{tabular}


The contents of major and selected trace elements in five PMGE (collected by PMGE staff) and five IMin (collected by I.M.) bulk samples of sulfide breccias (Table 2) were determined by titration ( $\mathrm{Fe}, \mathrm{Ca}, \mathrm{Mn}$ ), gravimetric analysis $(\mathrm{Si}, \mathrm{Ba}$ and $\mathrm{S}$ ) and atomic absorption spectrometry in air-acetylene flame on a Perkin-Elmer 3110 spectrometer $(\mathrm{Cu}, \mathrm{Zn}, \mathrm{Pb}, \mathrm{Ni}, \mathrm{Co}, \mathrm{Mo}, \mathrm{Cd}, \mathrm{Sn}, \mathrm{Au}$, and Ag) (PerkinElmer, Waltham, MA, USA) at the State Geological Enterprise Sevzapgeologiya (St. Petersburg) and IMin UB RAS. Two IMin samples of sulfide breccias (Table 3) were also analyzed for selected trace elements (V, Cr, Mn, Co, Ni, Cu, Zn, Ga, Ge, As, Se, Sr, Mo, Cd, Sn, Sb, Te, Ba, Tl, Pb, Bi, Th, U) on an ELAN 9000 (PerkinElmer, Waltham, MA, USA) ICP-MS quadrupole mass-spectrometer at the Institute of Geology and Geochemistry (IGG UB RAS), Yekaterinburg, Russia, calibrated against the USGS rock standard BCR-2, using In as an internal standard.

The chemical compositions of pyrite, chalcopyrite and bornite were analyzed on a CAMECA "CAMEBAX" electron microprobe (CAMECA, Gennevilliers Cedex, France) equipped with four vertical WDS spectrometers at the IGG-CNR, University of Padova, Italy. Analytical standards were pyrite (for $\mathrm{S}$ and $\mathrm{Fe}$ ), pure elements (for $\mathrm{Cu}, \mathrm{Co}, \mathrm{Ni}$, Se and $\mathrm{Au}$ ) and a synthetic arsenic-gallium alloy (for As). Analyses were carried out using a $1 \mu \mathrm{m}$ electron beam, $15 \mathrm{nA}$ beam current, $15 \mathrm{kV}$ accelerating voltage, and a counting time of $10 \mathrm{~s}$ for peak and $10 \mathrm{~s}$ for background. Detection limits for minor elements were ca. $0.06 \mathrm{wt} \%$ for $\mathrm{Co}$ and $\mathrm{Ni}, 0.07 \mathrm{wt} \%$ for $\mathrm{Cu}$ and Se, $0.12 \mathrm{wt} \%$ for As, and $0.20 \mathrm{wt} \%$ for $\mathrm{Au}$. The chemical compositions of rutile, jarosite, $\mathrm{HgS}$ phase and plagioclase were analyzed using a REMMA-202M SEM (Selmi, Sumy, Ukraine) equipped with a Link energy-dispersive spectrometer (EDS) with $1 \mu \mathrm{m}$ electron beam, $15 \mathrm{nA}$ beam current, $20 \mathrm{kV}$ accelerating voltage and a counting time of $120 \mathrm{~s}$ for peaks; the standard used was MINM-25-53 from ASTIMEX Scientific Limited (mineral mount No. 01-044).

Quantitative LA-ICP-MS analysis of pyrite, marcasite and chalcopyrite for major $\left({ }^{65} \mathrm{Cu},{ }^{66} \mathrm{Zn}\right)$ and selected trace elements $\left({ }^{51} \mathrm{~V},{ }^{55} \mathrm{Mn},{ }^{59} \mathrm{Co},{ }^{60} \mathrm{Ni},{ }^{65} \mathrm{Cu},{ }^{66} \mathrm{Zn},{ }^{75} \mathrm{As},{ }^{77} \mathrm{Se},{ }^{95} \mathrm{Mo},{ }^{107} \mathrm{Ag},{ }^{111} \mathrm{Cd},{ }^{117} \mathrm{Sn},{ }^{121} \mathrm{Sb}\right.$, ${ }^{125} \mathrm{Te},{ }^{182} \mathrm{~W},{ }^{197} \mathrm{Au},{ }^{205} \mathrm{Tl},{ }^{208} \mathrm{~Pb},{ }^{209} \mathrm{Bi},{ }^{238} \mathrm{U}$ ) was carried out on a New Wave 213-nm solid-state laser microprobe coupled to an Agilent 7700 quadrupole ICP-MS housed (Agilent Technologies, Santa Clara, CA, USA) at the CODES LA ICP MS analytical facility, University of Tasmania. The analyses were performed by ablating spots ranging in size from 40 to $60 \mu \mathrm{m}$. Laser repetition rate was $5 \mathrm{~Hz}$ and laser beam energy at the sample was maintained between 4 and $5 \mathrm{~J} / \mathrm{cm}^{2}$. The analysis time for each spot was $100 \mathrm{~s}$, comprising a 30-s measurement of background (laser off) and a 70-s measurement with laser on. Acquisition time for all masses was set to $0.02 \mathrm{~s}$. Data reduction was undertaken according to standard methods [43]. Iron was used as the internal standard for quantification of pyrite and chalcopyrite and $\mathrm{Zn}$ was used as the internal standard for quantification of sphalerite. Concentrations of the internal standard were calculated assuming stoichiometry. Detection limits were calculated as three times the standard error for the count rates of the instrument background signal (laser-off). An in-house Li-borate fused glass of a pyrite/sphalerite mixture [44] was used as the primary calibration standard. To account for the instrument drift, the standard was analyzed twice every one hour and a half, using a $100 \mu \mathrm{m}$ beam and a repetition rate of $10 \mathrm{~Hz}$, thus closely maintaining the aspect ratio between ablation craters on the samples and on the standard. The LA-ICP-MS analyses of pyrite and marcasite were processed in Statistica v. 6.0 program using correlation analysis and correlation matrices at confidence level of $95 \%$ are presented as Supplementary Materials.

LA-ICP-MS mapping of nodular pyrite was conducted on an Agilent 7700x mass spectrometer (Agilent Technologies, Santa Clara, CA, USA) equipped with a New Wave Research UP 213-nm solid-state laser and MassHunter software hosted at the IMin UB RAS at a laser beam energy of $3.5-4.5 \mathrm{~J} / \mathrm{cm}^{2}$, a laser repetition rate of $10 \mathrm{~Hz}$, a carrier gas of $\mathrm{He}$, and a flow rate of $0.65 \mathrm{~L} / \mathrm{min}$. The mass spectrometer was calibrated against standard multielemental solutions. The trace element maps were plotted with the Iolite program and are based on signal intensity during consecutive ablation of the nodule area with a laser beam of $12 \mu \mathrm{m}$ moving at a rate of $10 \mu \mathrm{m} / \mathrm{s}$ and a distance between ablation profiles of $12 \mu \mathrm{m}$. Both line and map analyses of pyrite were calibrated against MASS-1, a U.S. Geological Survey reference material, using values published in [45]. Iron was the internal standard. 


\section{Results}

\subsection{Textures, Structures, and Mineralogy of Sulfide Breccias}

Sulfide breccias from the Semenov-3 hydrothermal field were briefly described by Safina et al. [46]. Here, we significantly expand this description providing textural-structural relationships between sulfide clasts and authigenic mineral assemblages.

Sulfide breccias are composed of angular clasts of marcasite-pyrite aggregates up to $10 \mathrm{~cm}$ across and rare angular fragments of strongly altered volcanic rocks $\sim 1 \mathrm{~cm}$ in size (Figure 2 ). The clastic material is devoid of sorting and gradation bedding (Figure 2). The breccia matrix mostly consists of quartz accompanied by small $(<1 \mathrm{~cm})$ sulfide aggregates. These aggregates include clasts similar to large ones and newly formed sulfides. The major minerals of the breccias are pyrite, marcasite, and quartz, which are accompanied by barite and rare chalcopyrite, hematite, jarosite, bornite, sphalerite, pyrrhotite, covellite, $\mathrm{HgS}$ phase, rutile, chlorite and plagioclase.
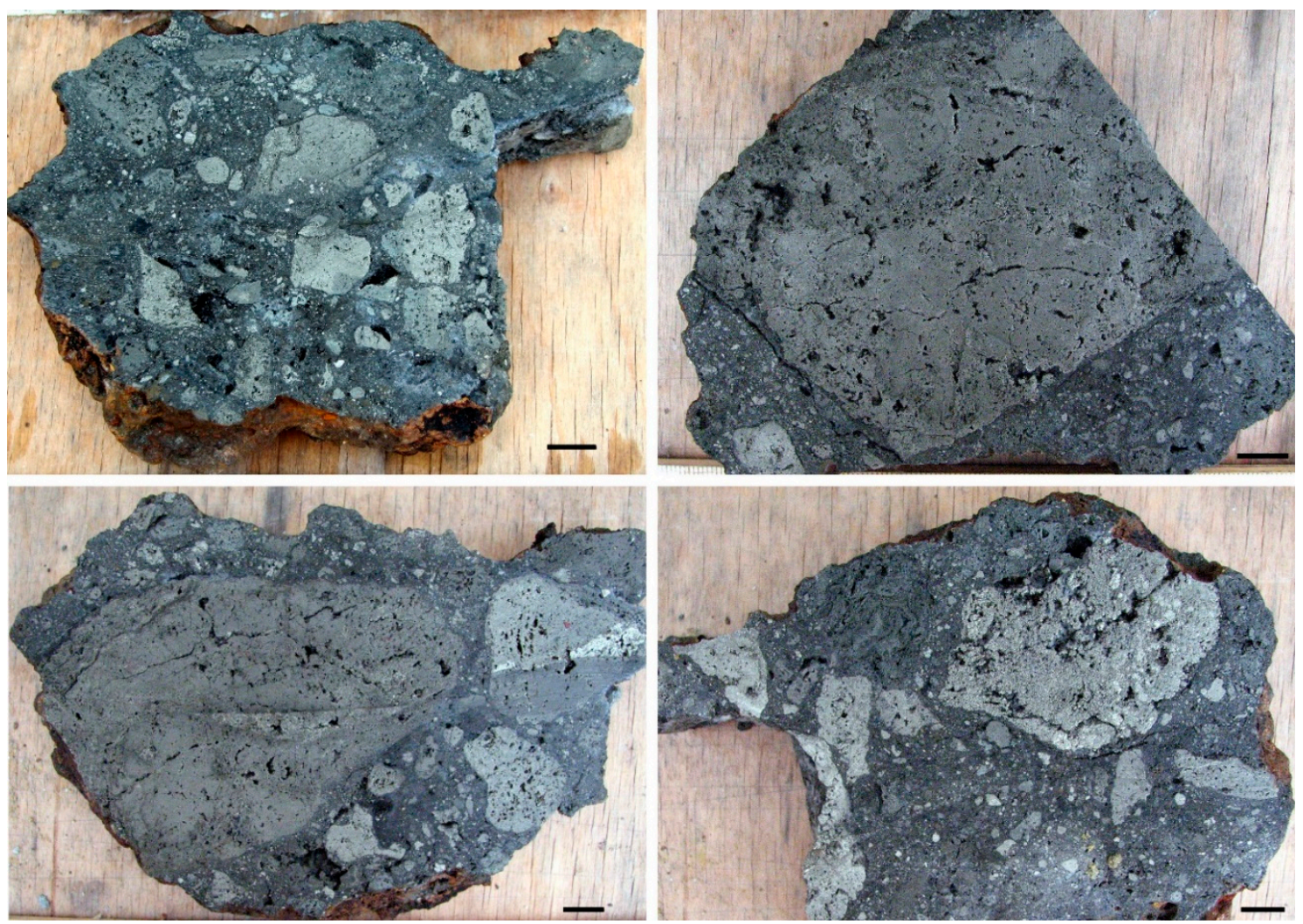

Figure 2. Sulfide breccias from the Semenov-3 hydrothermal field (on-board photographs). The scale bar is $1 \mathrm{~cm}$.

Marcasite-pyrite clasts exhibit colloform, concentric-zonal, massive, radial and porous structures. Colloform and concentric-zonal clasts consist of aggregates of dendritic, fine-grained and fine-crystalline pyrite and marcasite (Figure $3 a-c)$. Locally, the clasts contain small inclusions of chalcopyrite, sphalerite and barite. In concentric-zonal aggregates, marcasite typically overgrows pyrite (Figure $3 \mathrm{a}, \mathrm{d}, \mathrm{f}$ ) or occurs as fragments of radial aggregates up to $1 \mathrm{~mm}$ in size made of spear-like crystals (Figure 3f). 

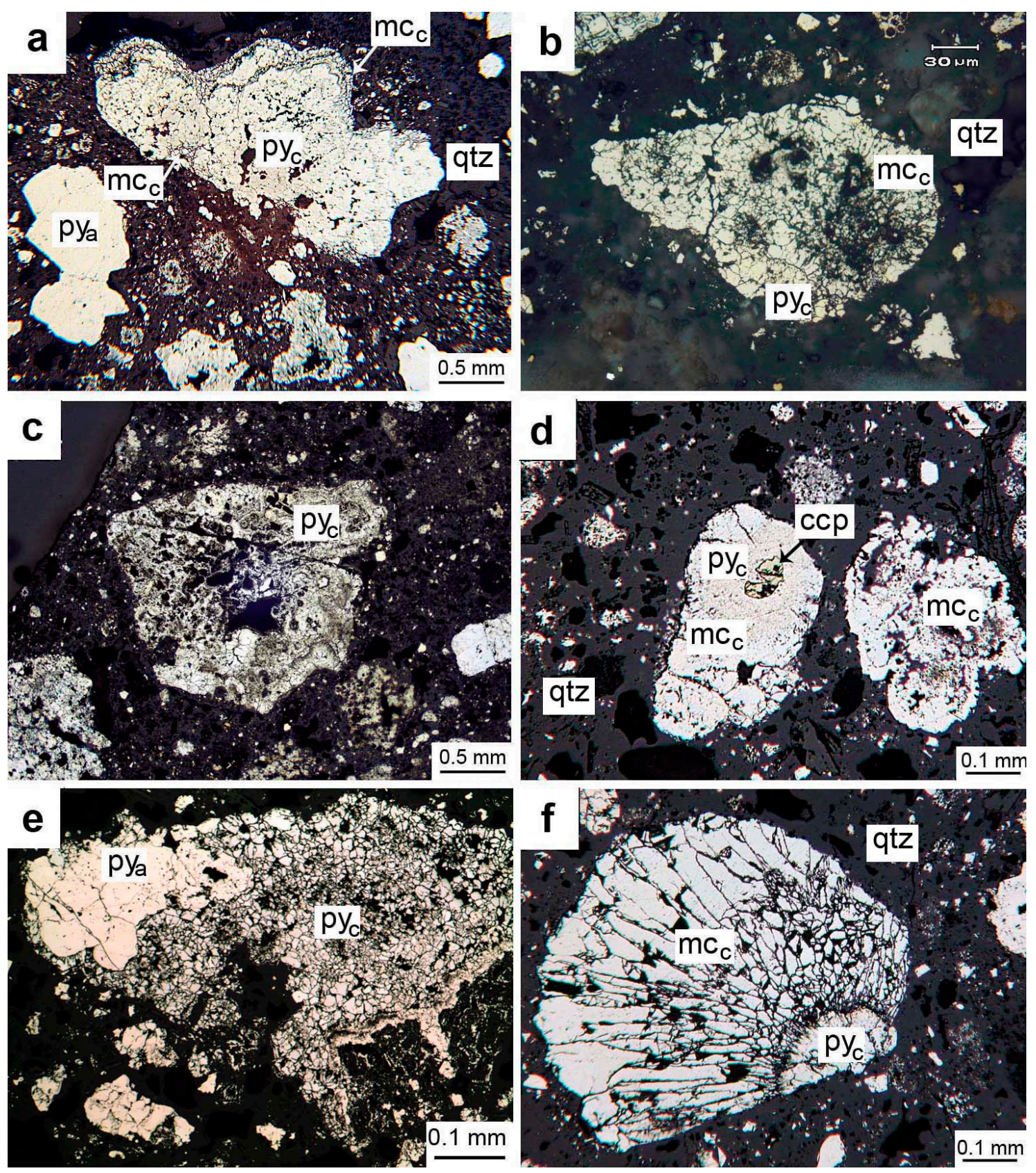

Figure 3. Clasts of fine-grained $(\mathbf{a}, \mathbf{b})$, colloform, porous $(\mathbf{c}, \mathbf{d})$, fine-crystalline $(\mathbf{e}, \mathbf{f})$ and radial $(\mathbf{a}, \mathbf{d}, \mathbf{f})$ aggregates of pyrite and marcasite from the Semenov-3 hydrothermal field. Here and hereafter, $\mathrm{py}_{\mathrm{c}}$, clastic pyrite; $\mathrm{mc}_{\mathrm{c}}$, clastic marcasite; pya, authigenic pyrite; $\mathrm{mc}_{\mathrm{a}}$, authigenic marcasite; ccp, chalcopyrite; qtz, quartz. Reflected light.

In the breccia matrix, pyrite and marcasite occur as small clasts or as individual crystals and their aggregates; pyrite also forms framboids, ovoids and nodules. Individual pyrite framboids or their coalesced aggregates are locally overgrown by crystalline pyrite (Figure 4a). Lens-like, ovoid or round porous fine-crystalline pyrite aggregates are composed of extremely small (1 to $3 \mu \mathrm{m})$ cubic crystals, often with round areas interpreted as former pyrite framboids (Figure $4 \mathrm{~b}$ ). Rare nodular pyrite aggregates are composed of two domains: a strongly porous center with inclusions of barite and quartz and a more compact exterior, which is made up of small intimately intergrown crystals of pyrite and less abundant marcasite, with fine $(<5 \mu \mathrm{m})$ inclusions of sphalerite, chalcopyrite, and pyrrhotite (Figures $4 \mathrm{c}$ and 5). Coarse-crystalline Fe disulfides are dominated by pyrite and contain minor 
marcasite. Coarse-crystalline pyrite is observed as euhedral to subhedral crystals and their aggregates in both the breccia matrix (Figure $3 a$,e and Figure $4 \mathrm{~d}-\mathrm{f}$ ) and within the pores of fine-grained clasts (Figure 5). Coarse-crystalline pyrite replaces clasts of fine-grained pyrite and is host to inclusions of pyrrhotite, chalcopyrite, sphalerite, and quartz (Figures $3 \mathrm{~d}$ and $4 \mathrm{e}, \mathrm{f}$ ). Some pyrite crystals contain "shadows" of earlier barite crystals (Figure $4 \mathrm{~d}$ ).
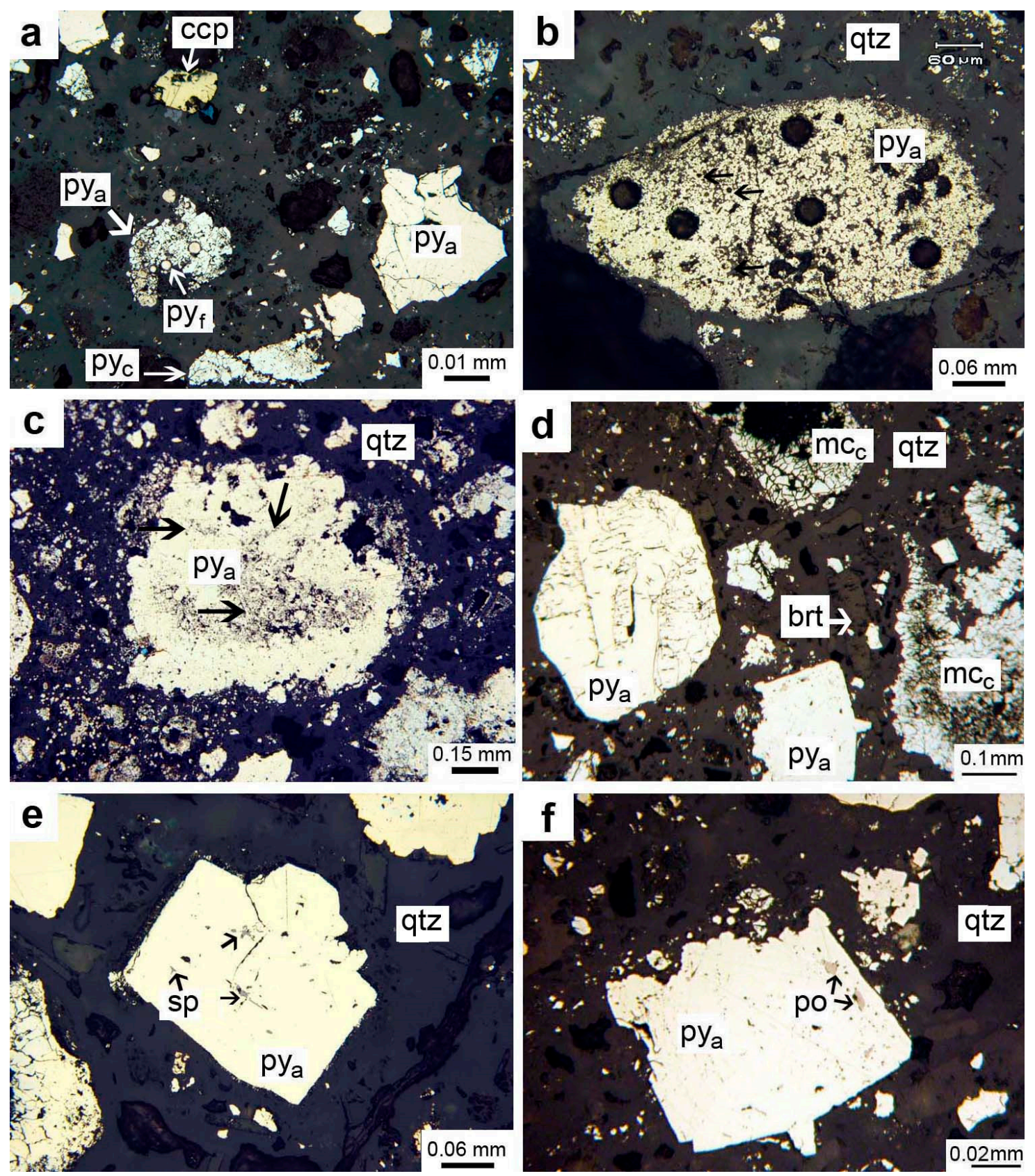

Figure 4. Authigenic forms of pyrite in breccia matrix from the Semenov-3 hydrothermal field: (a) framboidal pyrite $\left(\mathrm{py}_{\mathrm{f}}\right.$ ) overgrown by crystalline pyrite; (b) ovoid pyrite aggregate with relict framboidal structure (indicated by arrows; black dots are areas of LA-ICP-MS analysis); (c) pyrite nodule with porous center and crystalline exterior and inclusions of other sulfides and barite (indicated by arrows); (d) pyrite crystals developed after three crystals of barite (left), clasts of marcasite and individual barite crystals in the breccia matrix; (e) crystalline pyrite with inclusions of sphalerite; (f) crystalline pyrite with inclusions of pyrrhotite. Here and hereafter, ba, barite; sph, sphalerite; po, pyrrhotite. Reflected light. 

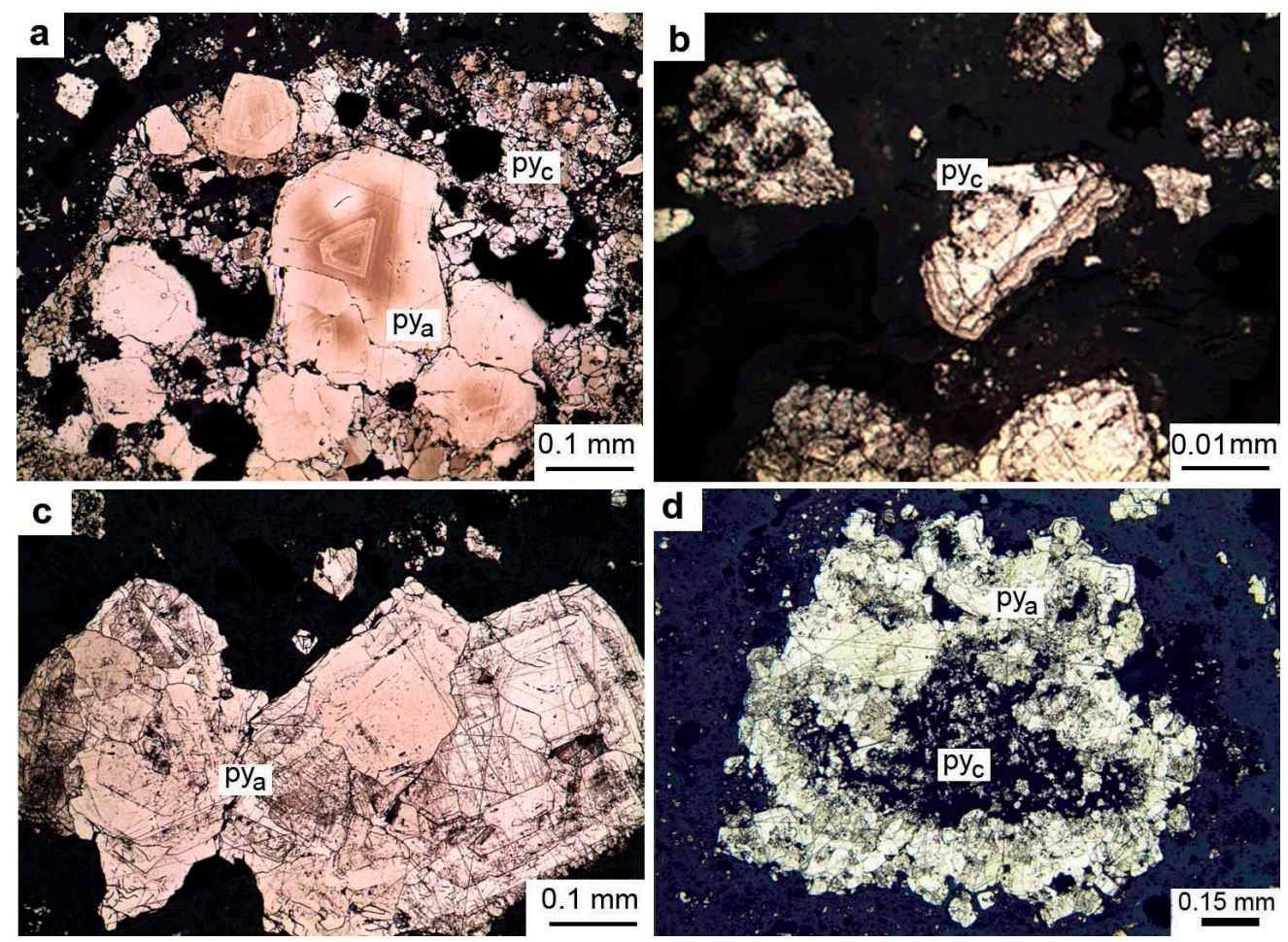

Figure 5. Clastic vs authigenic pyrite: (a) clast of fine-grained pyrite with numerous pores filled with authigenic zoned crystalline pyrite (zoning is emphasized by different tint of surficial oxidation of polished samples); (b) clast of zoned pyrite aggregate; (c) aggregate of zoned authigenic pyrite crystals; (d) pyrite nodule with central porous domain and polycrystalline outer rim. Reflected light. Photomicrographs (b-d), etched by $\mathrm{HNO}_{3}$.

Chalcopyrite in sulfide breccias occurs as (i) small subhedral to euhedral crystals and their aggregates in the breccia matrix and altered volcanic clasts (Figures 4a and 6a); (ii) individual acicular crystals and their radial aggregates in the breccia matrix (Figure 6b); (iii) zonal crystalline intergrowths with sphalerite in quartz (Figure 6c); (iv) small round grains and their aggregates in the breccia matrix, which replace and overgrow bornite from the rims, and rims around bornite and lamella inside it (Figure 6d,e); (v) rare inclusions in marcasite-pyrite clasts (Figure 3c); (vi) intergrowths with pyrrhotite and sphalerite inside crystalline pyrite crystals (Figure 6f); (vii) relatively large anhedral aggregates in the breccia matrix (Figure 6g); and (viii) single reniform aggregates (Figure 6h), which show radial structure after etching indicating possible replacement of radial marcasite aggregates abundant in sulfide breccias.

Bornite occurs as small $(\sim 10 \mu \mathrm{m})$ isometric grains in the breccia cement and quartz rims around pyrite crystals (Figure $6 \mathrm{~d}, \mathrm{e}$ ). It is typically associated with chalcopyrite, which forms lamellae inside bornite grains or rims around them. Covellite replaces the chalcopyrite grains and bornite-chalcopyrite intergrowths (Figure 6f). Pyrrhotite is observed as small $(<10 \mu \mathrm{m})$ individual anhedral grains or intergrowths with chalcopyrite and sphalerite, which fill the pores inside crystalline pyrite (Figures $4 \mathrm{f}$ and $6 \mathrm{~g}$ ), and as rare inclusions in crystalline chalcopyrite. Sphalerite forms crystalline aggregates in assemblage with crystalline chalcopyrite (see above) or subhedral grains up to $10 \mu \mathrm{m}$ in crystalline pyrite (Figures $4 \mathrm{e}$ and $6 \mathrm{~g}$ ). Hematite is found as globules $\sim 20 \mu \mathrm{m}$ in size in the quartz rims around pyrite clasts or as single specular crystals up to $70 \mu \mathrm{m}$ long and $\sim 5 \mu \mathrm{m}$ wide in the breccia cement (Figure 7a,b). A mineral with approximate composition $\mathrm{HgS}$ (cinnabar?) was found under the electron microscope as tiny $(\sim 1 \mu \mathrm{m}$ in size) round grains in chalcopyrite and pyrite crystals in the breccia cement (Figure 7c-e). Quartz composes most part of the breccia matrix also overgrowing the pyrite clasts and the barite crystals (Figures 3-7). Tabular barite crystals up to $1 \mathrm{~mm}$ in size fill fractures in 
the sulfide clasts, are present in the breccia matrix and form druses up to $0.5 \mathrm{~cm}$ thick (Figures $4 \mathrm{~d}$ and $7 \mathrm{f}$ ). Barite is locally associated with chalcopyrite. Jarosite replaces the marcasite-pyrite clasts from the margins (Figure 7g). Rutile, chlorite and plagioclase were found as inclusions ( 20 $\mu \mathrm{m}$ in size) in the coarser-crystalline pyrite.
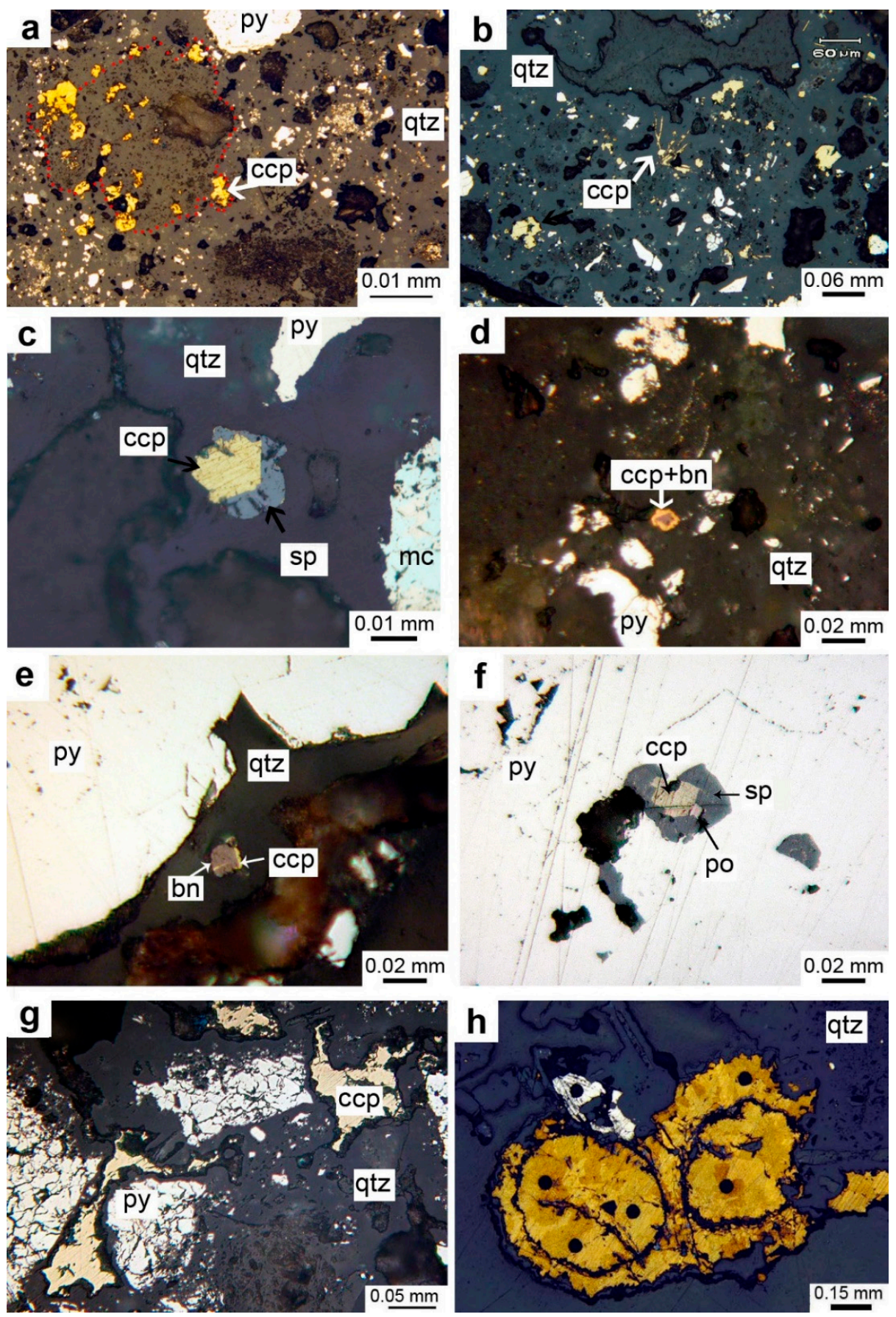

Figure 6. Morphological varieties of chalcopyrite and bornite in sulfide breccias from the Semenov-3 hydrothermal field: (a) chalcopyrite crystals inside the volcanic clast (emphasized by red dots) and the matrix; (b) radial aggregate of acicular chalcopyrite crystals in quartz; (c) fragmented crystalline chalcopyrite overgrown by sphalerite crystal; (d) small bornite grain with chalcopyrite rim inside quartz; (e) bornite grain with chalcopyrite lamella and rim; (f) pyrrhotite-chalcopyrite-sphalerite assemblage in crystalline pyrite; (g) anhedral chalcopyrite aggregates in quartz; (h) reniform chalcopyrite after radial marcasite aggregate (etched by vapors of a $\mathrm{HNO}_{3}+\mathrm{HCl}$ mixture; black dots are areas of LA-ICP-MS analysis). 

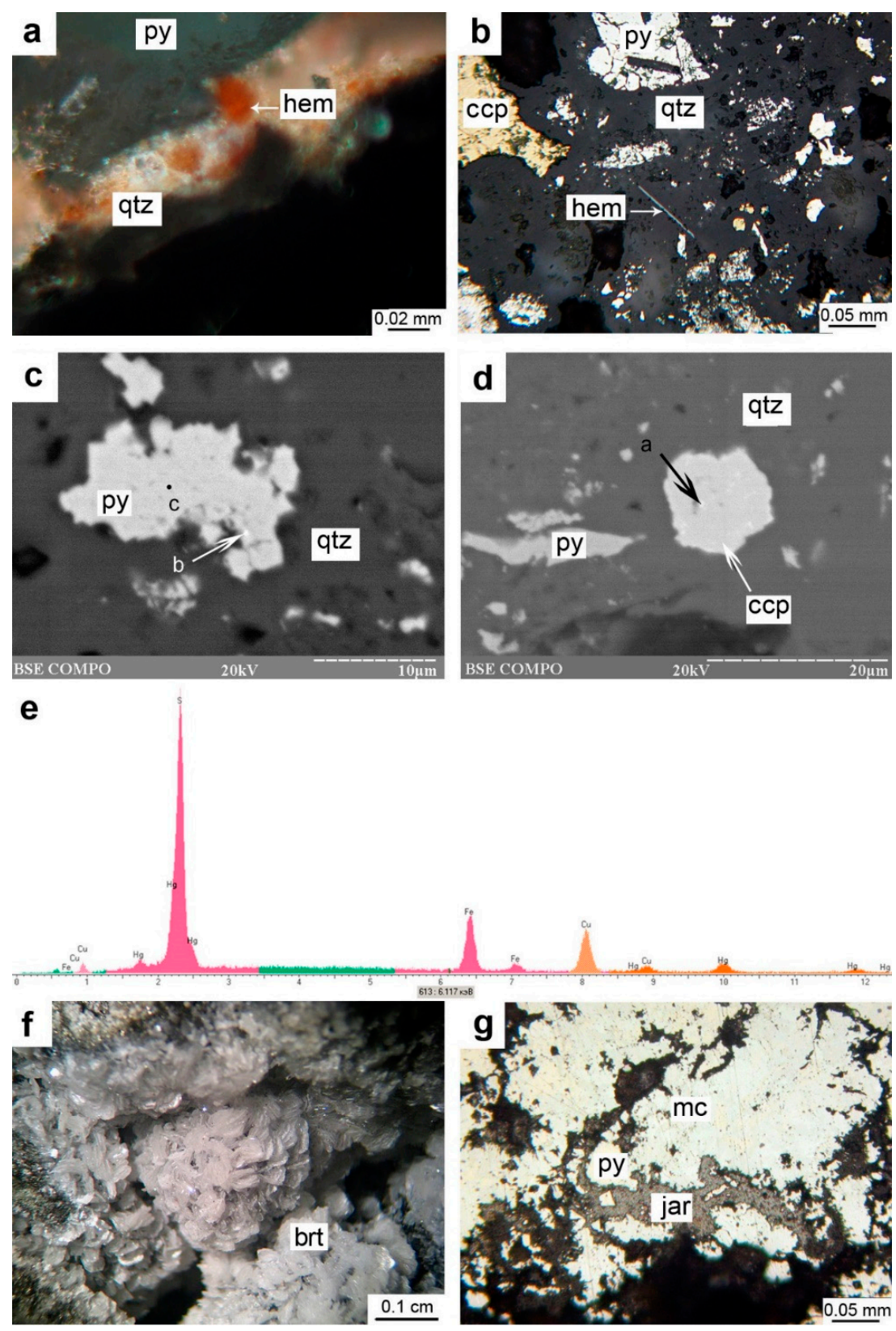

Figure 7. Accessory minerals of sulfide breccias from the Semenov-3 hydrothermal field: (a) hematite globule within the quartz rim around authigenic pyrite; (b) specular hematite crystal in the breccia cement; (c) inclusion of $\mathrm{HgS}$ phase (point b) in crystalline pyrite aggregate; (d) inclusion of $\mathrm{HgS}$ phase (point a) in chalcopyrite grain; (e) EDS spectrum of a mixture of chalcopyrite and HgS phase; (f) barite druse in the cavity of sulfide breccia; (g) jarosite (jar) replacing marcasite-pyrite aggregate from the rim. figure $a, b, g$, reflected light; figure c, d, back-scattered electron images; figure f, binocular microscope.

\subsection{Bulk Chemistry}

Representative bulk major- and trace-element compositions of the massive sulfide breccias are shown in Tables 2 and 3. ICP-MS and atomic absorption analyses yielded comparable results. The dominant elements are Fe and S, the contents of which vary from 25.81 to 63.06 wt \% for Fe and from 22.21 to $46.22 \mathrm{wt} \%$ for $\mathrm{S}$. The contents of the most valuable elements are low, reaching wt $\%$ concentrations of 0.21 for $\mathrm{Cu}, 0.15$ for $\mathrm{Zn}$ and 0.02 for $\mathrm{Pb}$. The concentrations of trace metals are also low (max): 0.003 wt \% Ni, 0.013 wt \% Co, 0.001 wt \% Mo, 11.25 ppm Cd, 48.58 ppm Sn, 20.4 ppm Ag and $0.63 \mathrm{ppm} \mathrm{Au}$. The breccias also contain $\mathrm{Si}, \mathrm{Ba}, \mathrm{Ca}$ and $\mathrm{Mg}$ (Table 2). 
Table 2. Chemical composition of sulfide breccias from the Semenov-3 hydrothermal field.

\begin{tabular}{|c|c|c|c|c|c|c|c|c|c|c|c|c|c|c|c|c|c|}
\hline \multirow{2}{*}{ Sample Number } & $\mathbf{F e}$ & $\mathbf{S}$ & $\mathrm{Cu}$ & Zn & $\mathrm{Pb}$ & Si & $\mathrm{Ca}$ & Mn & $\mathrm{Mg}$ & $\mathbf{B a}$ & $\mathrm{Ni}$ & Co & Mo & Cd & Sn & Ag & Au \\
\hline & \multicolumn{13}{|c|}{ wt $\%$} & \multicolumn{4}{|c|}{ ppm } \\
\hline \multicolumn{18}{|c|}{ Polar Marine Geosurvey Expedition (PMGE) Data } \\
\hline 284-B2 & 44.34 & 46.22 & 0.21 & 0.10 & 0.02 & 0.13 & 0.70 & 0.02 & 0.12 & 0.88 & 0.003 & 0.003 & 0.001 & 8.45 & 7.90 & 11.6 & 0.63 \\
\hline 284-B3 & 37.73 & 39.99 & 0.15 & 0.03 & 0.01 & 7.35 & 0.60 & 0.01 & 0.12 & 0.53 & 0.003 & 0.013 & 0.001 & 6.55 & 16.62 & 10.3 & 0.29 \\
\hline 284-B4 & 38.38 & 36.50 & 0.15 & 0.15 & 0.01 & 4.91 & 0.70 & 0.01 & 0.12 & 0.88 & 0.002 & 0.007 & $<0.001$ & 10.55 & 29.93 & 6.3 & 0.53 \\
\hline 284-B5 & 25.81 & 28.31 & 0.20 & 0.04 & 0.01 & 13.75 & 0.99 & 0.01 & 0.11 & 2.59 & 0.003 & 0.006 & $<0.001$ & 5.45 & 48.58 & 10.0 & 0.36 \\
\hline 284-B7 & 32.28 & 33.68 & 0.12 & 0.06 & 0.01 & 6.27 & 0.70 & 0.01 & 0.10 & 4.12 & 0.003 & 0.002 & $<0.001$ & 6.90 & 10.38 & 17.4 & 0.28 \\
\hline median & 37.73 & 36.50 & 0.15 & 0.06 & 0.01 & 6.27 & 0.70 & 0.01 & 0.12 & 0.88 & 0.003 & 0.006 & 0.001 & 6.90 & 16.62 & 10.3 & 0.36 \\
\hline \multirow[t]{2}{*}{ IMin Data } & & & & & & $\mathrm{SiO}_{2}$ & $\mathrm{CaO}$ & $\mathrm{MnO}$ & $\mathrm{MgO}$ & & & & & & & & \\
\hline & \multicolumn{2}{|c|}{ wt \% } & & ppm & \multicolumn{6}{|c|}{ wt \% } & \multicolumn{7}{|c|}{ ppm } \\
\hline $284-a$ & 47.47 & 22.98 & 2119 & 375 & 47.50 & 22.74 & 0.02 & 0.01 & 0.04 & n.a. & 47.50 & 23.75 & n.a. & 8.00 & n.a. & 12.7 & 0.48 \\
\hline $284-b$ & 35.82 & 21.21 & 2706 & 419 & 31.50 & 37.60 & 0.01 & 0.01 & 0.05 & n.a. & 56.75 & 55.75 & n.a. & 6.50 & n.a. & 20.4 & 0.34 \\
\hline $284-\mathrm{c}$ & 49.37 & 22.62 & 665 & 265 & 52.75 & 22.62 & 0.01 & 0.01 & 0.03 & n.a. & 34.75 & 51.00 & n.a. & 9.50 & n.a. & 9.3 & 0.39 \\
\hline $284-d$ & 45.00 & 23.96 & 1600 & 351 & 57.75 & 26.18 & 0.01 & 0.01 & 0.02 & n.a. & 47.75 & 35.00 & n.a. & 7.25 & n.a. & 11.8 & 0.32 \\
\hline 284-e & 63.06 & 21.57 & 328 & 135 & 28.25 & 3.00 & 0.01 & 0.01 & 0.01 & n.a. & 95.75 & 51.25 & n.a. & 11.25 & n.a. & 5.8 & 0.20 \\
\hline median & 47.47 & 22.62 & 1600 & 351 & 47.5 & 22.74 & 0.01 & 0.01 & 0.03 & & 47.75 & 51 & & 8 & & 11.8 & 0.34 \\
\hline
\end{tabular}

Table 3. Trace element composition of sulfide breccias from the Semenov-3 hydrothermal field, ppm (IMin data).

\begin{tabular}{cccccccccccccccccccccccccc}
\hline Sample Number & $\mathbf{V}$ & $\mathbf{C r}$ & $\mathbf{M n}$ & $\mathbf{C o}$ & $\mathbf{N i}$ & $\mathbf{C u}$ & $\mathbf{Z n}$ & $\mathbf{G a}$ & $\mathbf{G e}$ & $\mathbf{A s}$ & $\mathbf{S e}$ & $\mathbf{S r}$ & $\mathbf{M o}$ & $\mathbf{C d}$ & $\mathbf{S n}$ & $\mathbf{S b}$ & $\mathbf{T e}$ & $\mathbf{B a}$ & $\mathbf{T l}$ & $\mathbf{P b}$ & $\mathbf{B i}$ & $\mathbf{T h}$ & $\mathbf{U}$ \\
\hline 284-a & 3.30 & 19 & 83 & 24 & 13 & 751 & 203 & 0.39 & 0.11 & 148 & 38 & 77 & 30 & 0.47 & 1.99 & 2.09 & 0.08 & 1182 & 6.31 & 72 & 0.12 & 0.06 & 1.34 \\
$284-\mathbf{b}$ & 4.21 & 46 & 45 & 38 & 12 & 1745 & 257 & 0.39 & 0.06 & 123 & 44 & 116 & 37 & 0.94 & 3.34 & 2.45 & 0.76 & 1340 & 5.69 & 85 & 0.43 & 0.01 & 0.72 \\
\hline
\end{tabular}




\subsection{Trace Element Composition of Sulfides}

According to microprobe analyses, pyrite does not contain significant $\mathrm{Cu}, \mathrm{As}, \mathrm{Ni}$ and $\mathrm{Se}$, which are all below their respective detection limits (Table 4). Chalcopyrite is locally characterized by the presence of detectable Co and $\mathrm{Ni}(\leq 0.06 \mathrm{wt} \%)$, Se $(\leq 0.30 \mathrm{wt} \%)$, and $\mathrm{Au}(\leq 0.43 \mathrm{wt} \%)$ (Table 4$)$. The LA-ICP-MS analyses (Table 5) allow us to describe in better detail the different associations of minor and trace elements in major minerals: clastic fine-crystalline, ovoid fine-crystalline and coarse-crystalline pyrite, marcasite and authigenic reniform chalcopyrite.

Table 4. Composition of selected sulfides according to microprobe analysis, wt $\%$.

\begin{tabular}{|c|c|c|c|c|c|c|c|c|c|}
\hline Number of Analysis & $\mathbf{F e}$ & $\mathrm{Cu}$ & $\mathbf{S}$ & Co & $\mathrm{Ni}$ & As & Se & $\mathrm{Au}$ & Total \\
\hline \multicolumn{10}{|c|}{ Pyrite } \\
\hline $284-3-5-1$ & 47.75 & $<0.07$ & 53.18 & $<0.06$ & $<0.06$ & $<0.12$ & $<0.07$ & $<0.20$ & 101.00 \\
\hline $284-3-5-3$ & 47.85 & $<0.07$ & 53.12 & $<0.06$ & $<0.06$ & $<0.12$ & $<0.07$ & $<0.20$ & 101.07 \\
\hline $284-3-7-13$ & 47.21 & $<0.07$ & 53.47 & $<0.06$ & $<0.06$ & $<0.12$ & $<0.07$ & $<0.20$ & 100.75 \\
\hline \multicolumn{10}{|c|}{ Chalcopyrite } \\
\hline $284-3-7-1$ & 29.92 & 33.05 & 35.08 & $<0.06$ & $<0.06$ & $<0.12$ & 0.08 & $<0.20$ & 98.15 \\
\hline $284-3-7-8$ & 30.09 & 33.26 & 34.79 & $<0.06$ & $<0.06$ & $<0.12$ & $<0.07$ & $<0.20$ & 98.14 \\
\hline $284-3-7-9$ & 30.10 & 33.77 & 34.98 & $<0.06$ & $<0.06$ & $<0.12$ & $<0.07$ & $<0.20$ & 98.91 \\
\hline $284-3-7-10$ & 29.65 & 33.47 & 34.60 & $<0.06$ & $<0.06$ & $<0.12$ & $<0.07$ & 0.43 & 98.15 \\
\hline $284-3-7-23$ & 30.36 & 33.95 & 34.69 & $<0.06$ & $<0.06$ & $<0.12$ & 0.30 & $<0.20$ & 99.35 \\
\hline $284-3-7-22$ & 30.05 & 34.21 & 34.90 & $<0.06$ & $<0.06$ & $<0.12$ & $<0.07$ & $<0.20$ & 99.20 \\
\hline
\end{tabular}

The ovoid fine-crystalline pyrite has high median contents (>1000 ppm) of $\mathrm{Cu}$ and $\mathrm{Zn}$, moderate median contents ( $>100 \mathrm{ppm}$ ) of $\mathrm{Mn}$, As and $\mathrm{Pb}$, low median contents ( $>10 \mathrm{ppm})$ of Se and Ag, and very low median contents $(<10 \mathrm{ppm}$ ) of other elements (Table 5). The ovoid pyrite exhibits several distinct correlations between different trace elements (Supplementary Materials, Figure 8). In this pyrite, $\mathrm{V}$ is positively correlated with $\mathrm{Pb}$ and $\mathrm{Au}$. Lead is positively correlated with $\mathrm{Co}, \mathrm{Ni}, \mathrm{Cu}, \mathrm{Zn}, \mathrm{Se}, \mathrm{Ag}, \mathrm{Sn}$ and $\mathrm{Bi}$. Gold is only correlated with $\mathrm{Sb}$. Cobalt and $\mathrm{Ni}$ are mutually correlated and have correlations with $\mathrm{Sn}, \mathrm{Cu}, \mathrm{Se}, \mathrm{Te}, \mathrm{Pb}$ and $\mathrm{Bi}$. Nickel is also correlated with $\mathrm{Mn}$ and $\mathrm{Sb}$. Manganese has correlations with $\mathrm{Se}, \mathrm{Sn}, \mathrm{Ni}$ and $\mathrm{Bi}$. In addition to above mentioned correlations with $\mathrm{Ni}, \mathrm{Co}, \mathrm{Se}, \mathrm{Pb}$ and $\mathrm{Bi}, \mathrm{Cu}$ is also positively correlated with $\mathrm{Zn}$ and $\mathrm{U}$. Zinc is positively correlated with $\mathrm{Cd}, \mathrm{Cu}$ and $\mathrm{Pb}$ and, as well as $\mathrm{Cd}$, is negatively correlated with $\mathrm{As}$ and $\mathrm{W}$, which have positive correlation between each other. Selenium is correlated with $\mathrm{Mn}, \mathrm{Co}, \mathrm{Ni}, \mathrm{Cu}, \mathrm{Ag}, \mathrm{Sn}, \mathrm{Sb}, \mathrm{Pb}$ and $\mathrm{Bi}$. Silver is correlated with $\mathrm{Se}, \mathrm{Pb}$ and Bi. Molybdenum and $\mathrm{Tl}$ show no correlations with any element. 
Table 5. Trace element composition of sulfides from the Semenov-3 hydrothermal field (ppm).

\begin{tabular}{|c|c|c|c|c|c|c|c|c|c|c|c|c|c|c|c|c|c|c|c|c|}
\hline & ${ }^{51} \mathrm{~V}$ & ${ }^{55} \mathrm{Mn}$ & ${ }^{59} \mathrm{Co}$ & ${ }^{60} \mathrm{Ni}$ & ${ }^{65} \mathrm{Cu}$ & ${ }^{66} \mathrm{Zn}$ & ${ }^{75} \mathrm{As}$ & ${ }^{77} \mathrm{Se}$ & ${ }^{95} \mathrm{Mo}$ & ${ }^{107} \mathrm{Ag}$ & ${ }^{111} \mathrm{Cd}$ & ${ }^{118} \mathrm{Sn}$ & ${ }^{121} \mathrm{Sb}$ & ${ }^{125} \mathrm{Te}$ & ${ }^{182} \mathrm{~W}$ & ${ }^{197} \mathrm{Au}$ & ${ }^{205} \mathrm{Tl}$ & ${ }^{208} \mathrm{~Pb}$ & ${ }^{209} \mathrm{Bi}$ & $\overline{238} U$ \\
\hline \multicolumn{21}{|c|}{ Clastic Fine-Crystalline Pyrite (8) } \\
\hline $\mathrm{m}$ & $0.92 \mathrm{~d}$ & 95 & 12 & 2.36 & 715 & 169 & 186 & 19 & 35 & 15 & 0.27 & 1.38 & 1.00 & 0.44 & 0.24 & 0.12 & 10 & 79 & 0.15 & 0.38 \\
\hline av & 1.78 & 136 & 37 & 27 & 2417 & 528 & 236 & 148 & 139 & 66 & 0.66 & 3.95 & 6.33 & 0.83 & 0.40 & 2.14 & 12 & 216 & 0.52 & 0.60 \\
\hline $\min$ & 0.54 & 5.09 & 0.17 & 0.16 & 16 & 17 & 63 & 2.65 & 2.17 & 0.08 & 0.02 & 0.06 & 0.15 & 0.05 & 0.06 & 0.04 & 0.44 & 2.35 & 0.00 & 0.02 \\
\hline $\max$ & 5.99 & 422 & 123 & 128 & 12913 & 2191 & 463 & 481 & 696 & 333 & 1.96 & 20 & 32 & 3.15 & 1.33 & 11 & 41 & 772 & 1.82 & 2.23 \\
\hline \multicolumn{21}{|c|}{ Ovoid Fine-Crystalline Pyrite (6) } \\
\hline $\mathrm{m}$ & 1.17 & 180 & 10 & 6.82 & 2913 & 2524 & 140 & 90 & 3.68 & 59 & 3.12 & 1.88 & 4.47 & 0.21 & 0.49 & 0.29 & 9.69 & 264 & 0.18 & 1.87 \\
\hline av & 1.20 & 243 & 11 & 6.68 & 2544 & 2161 & 240 & 100 & 3.22 & 56 & 2.76 & 1.83 & 4.49 & 0.36 & 0.53 & 0.29 & 10 & 259 & 0.16 & 1.74 \\
\hline $\min$ & 0.86 & 12 & 1.52 & 1.25 & 379 & 144 & 33 & 10 & 1.64 & 5.77 & 0.44 & 0.35 & 3.26 & 0.01 & 0.32 & 0.09 & 8.53 & 56 & 0.01 & 0.85 \\
\hline $\max$ & 1.73 & 490 & 19 & 12 & 3662 & 2867 & 834 & 184 & 4.37 & 105 & 3.99 & 3.03 & 5.74 & 0.83 & 1.00 & 0.49 & 12 & 396 & 0.28 & 2.24 \\
\hline \multicolumn{21}{|c|}{ Coarse-Crystalline Pyrite (7) } \\
\hline $\mathrm{m}$ & 0.07 & 0.92 & 177 & 16 & 21 & 4.61 & 75 & 59 & 0.19 & 0.05 & 0.03 & 0.19 & 1.00 & 2.86 & 0.05 & 0.01 & 0.01 & 8.79 & 1.05 & 0.09 \\
\hline av & 0.34 & 3.73 & 339 & 67 & 82 & 21 & 251 & 120 & 10 & 0.32 & 0.03 & 0.21 & 0.86 & 2.40 & 0.12 & 0.07 & 3.07 & 11 & 3.23 & 0.08 \\
\hline $\min$ & 0.00 & 0.09 & 0.40 & 0.05 & 1.02 & 0.00 & 2.96 & 23.67 & 0.00 & 0.01 & 0.01 & 0.05 & 0.00 & 0.01 & 0.00 & 0.00 & 0.00 & 0.01 & 0.03 & 0.00 \\
\hline $\max$ & 1.03 & 13 & 1445 & 375 & 484 & 109 & 1140 & 318 & 54 & 1.28 & 0.05 & 0.40 & 2.06 & 5.81 & 0.52 & 0.23 & 19 & 28 & 13 & 0.22 \\
\hline \multicolumn{21}{|c|}{ Marcasite (9) } \\
\hline $\mathrm{m}$ & 0.68 & 14 & 1.50 & 2.09 & 276 & 58 & 100 & 26 & 21 & 7.76 & 0.09 & 0.52 & 0.29 & 0.16 & 0.31 & 0.06 & 13 & 26 & 0.06 & 0.17 \\
\hline av & 1.29 & 22 & 18 & 3.49 & 474 & 265 & 99 & 45 & 31 & 12 & 0.65 & 0.68 & 1.02 & 0.61 & 0.35 & 0.10 & 15 & 67 & 1.10 & 0.16 \\
\hline $\min$ & 0.14 & 0.87 & 0.01 & 0.37 & 14 & 1.38 & 0.86 & 0.01 & 0.42 & 0.33 & 0.01 & 0.02 & 0.02 & 0.01 & 0.02 & 0.01 & 2.31 & 5.26 & 0.00 & 0.00 \\
\hline $\max$ & 5.01 & 51 & 140 & 16 & 1422 & 1649 & 172 & 173 & 96 & 33 & 4.82 & 2.25 & 4.36 & 4.20 & 0.84 & 0.37 & 45 & 345 & 9.55 & 0.40 \\
\hline \multicolumn{21}{|c|}{ Reniform Chalcopyrite (5) } \\
\hline $\mathrm{m}$ & 8.86 & 0.85 & 0.08 & 0.16 & 350904 & 210 & 895 & 2.78 & 0.27 & 13 & 0.08 & 0.32 & 1.16 & 0.12 & 0.69 & 0.02 & 1.04 & 738 & 0.00 & 0.00 \\
\hline av & 7.59 & 0.75 & 0.11 & 0.18 & 350799 & 268 & 1445 & 11 & 13 & 22 & 0.08 & 0.32 & 125 & 0.11 & 6.45 & 0.02 & 2.95 & 879 & 0.01 & 0.00 \\
\hline & ${ }^{51} \mathrm{~V}$ & ${ }^{55} \mathrm{Mn}$ & ${ }^{59} \mathrm{Co}$ & ${ }^{60} \mathrm{Ni}$ & ${ }^{65} \mathrm{Cu}$ & ${ }^{66} \mathrm{Zn}$ & ${ }^{75} \mathrm{As}$ & ${ }^{77} \mathrm{Se}$ & ${ }^{95} \mathrm{Mo}$ & ${ }^{107} \mathrm{Ag}$ & ${ }^{111} \mathrm{Cd}$ & ${ }^{118} \mathrm{Sn}$ & ${ }^{121} \mathrm{Sb}$ & ${ }^{125} \mathrm{Te}$ & ${ }^{182} \mathrm{~W}$ & ${ }^{197} \mathrm{Au}$ & ${ }^{205} \mathrm{Tl}$ & ${ }^{208} \mathrm{~Pb}$ & ${ }^{209} \mathrm{Bi}$ & ${ }^{238} \mathrm{U}$ \\
\hline $\min$ & 2.01 & 0.22 & 0.05 & 0.07 & 348967 & 110 & 494 & 1.54 & 0.15 & 11 & 0.01 & 0.26 & 0.39 & 0.01 & 0.00 & 0.00 & 0.82 & 460 & 0.00 & 0.00 \\
\hline $\max$ & 12 & 1.29 & 0.19 & 0.27 & 352425 & 444 & 3675 & 40 & 38 & 58 & 0.16 & 0.37 & 326 & 0.18 & 18 & 0.03 & 6.83 & 1330 & 0.01 & 0.00 \\
\hline \multicolumn{21}{|c|}{ Clastic Crystalline Chalcopyrite (3) } \\
\hline $\mathrm{m}$ & 21 & 6.11 & 8.40 & 1.95 & 323647 & 264 & 375 & 639 & 31 & 110 & 0.07 & 8.75 & 17 & 0.45 & 4.55 & 0.10 & 2.41 & 349 & 0.10 & 0.17 \\
\hline av & 18 & 8.22 & 5.94 & 1.81 & 325500 & 225 & 449 & 617 & 23 & 407 & 0.13 & 9.97 & 11 & 0.84 & 15 & 0.17 & 3.22 & 396 & 0.16 & 0.13 \\
\hline $\min$ & 12 & 0.63 & 0.07 & 0.01 & 299448 & 141 & 195 & 11 & 0.28 & 3.63 & 0.07 & 0.37 & 0.19 & 0.23 & 3.60 & 0.01 & 1.65 & 256 & 0.00 & 0.00 \\
\hline $\max$ & 21 & 18 & 9.34 & 3.46 & 344139 & 271 & 778 & 1202 & 38 & 1106 & 0.24 & 21 & 17 & 1.85 & 38 & 0.41 & 5.60 & 584 & 0.37 & 0.21 \\
\hline
\end{tabular}



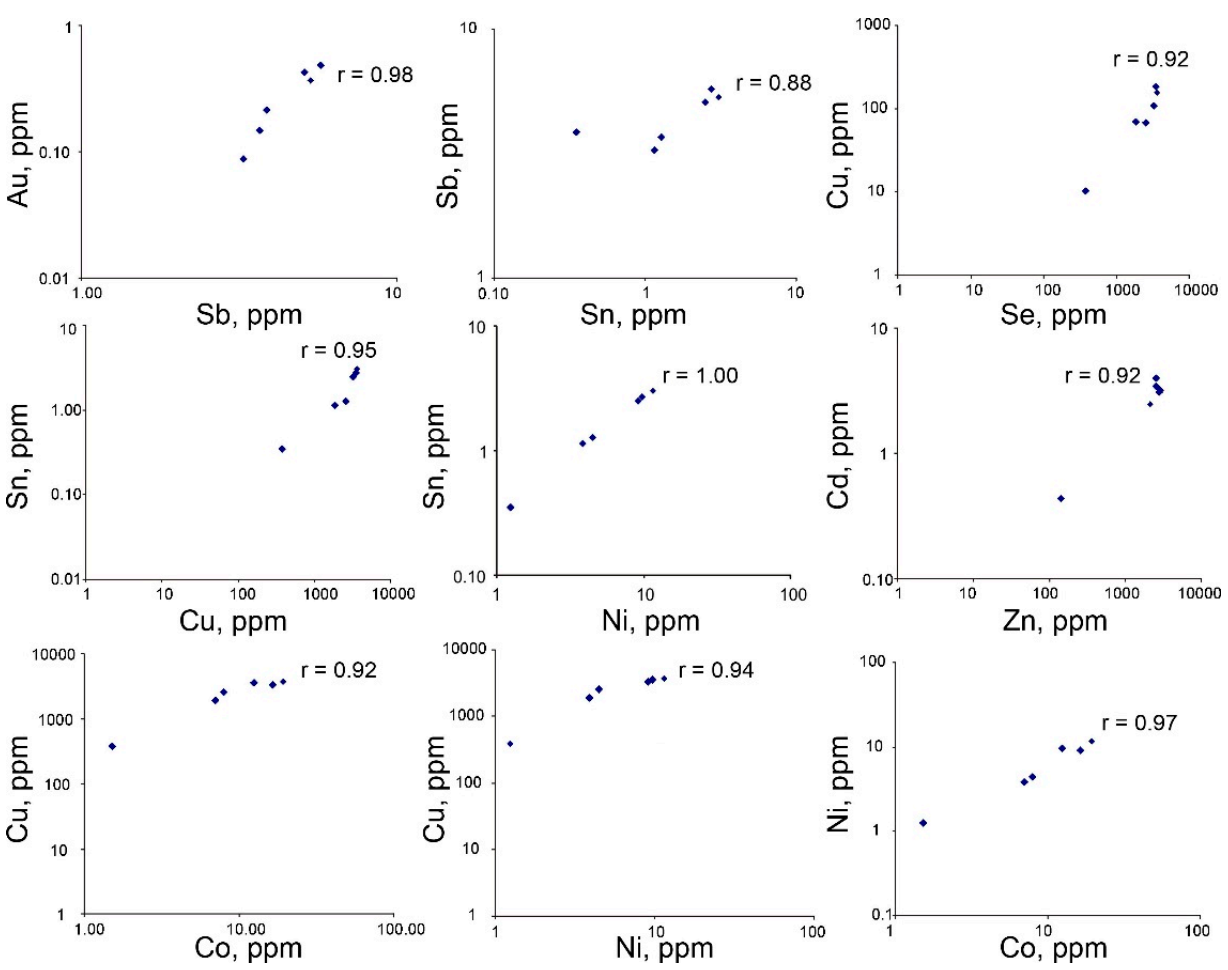

Figure 8. Log-log plots for selected trace elements in ovoid fine-crystalline pyrite (ppm). Here and in Figures 9 and 11, correlation coefficients are taken from correlation matrices (Supplementary Materials).

The clastic fine-crystalline pyrite is characterized by moderate median contents ( $>100 \mathrm{ppm})$ of $\mathrm{Cu}$, $\mathrm{Zn}$ and As, low median contents ( $>10 \mathrm{ppm})$ of $\mathrm{Mn}, \mathrm{Mo}$ and $\mathrm{Ag}$, and very low median contents $(<10 \mathrm{ppm})$ of other elements (Table 5). The contents of $\mathrm{Tl}$ and $\mathrm{Bi}$ are similar in ovoid and clastic fine-crystalline pyrite. The fine-crystalline pyrite is characterized by a number of positively correlated trace element pairs, such as $\mathrm{Cu}-\mathrm{Ni}, \mathrm{Cu}-\mathrm{Se}, \mathrm{Cu}-\mathrm{Sn}, \mathrm{V}-\mathrm{As}, \mathrm{V}-\mathrm{Cd}, \mathrm{Zn}-\mathrm{Se}, \mathrm{Zn}-\mathrm{W}$, Se-Ag, Se-Au, Mo-Tl, Ag-Sb, Ag-Sn, $\mathrm{Sn}-\mathrm{Sb}, \mathrm{Te}-\mathrm{Cu}, \mathrm{Te}-\mathrm{Pb}, \mathrm{Bi}-\mathrm{Te}, \mathrm{Bi}-\mathrm{U}, \mathrm{U}-\mathrm{Au}$ and others (Supplementary Materials, Figure 9). Manganese has no correlations with any element. Relative to ovoidal fine-crystalline pyrite, the fine-crystalline pyrite is enriched in $\mathrm{Co}, \mathrm{As}, \mathrm{Mo}$, and Te, and poorer in V, Mn, Ni, Cu, Zn, Se, Ag, Cd, Sn, Sb, W, Au, $\mathrm{Pb}$ and $\mathrm{U}$ (Figure 10a).
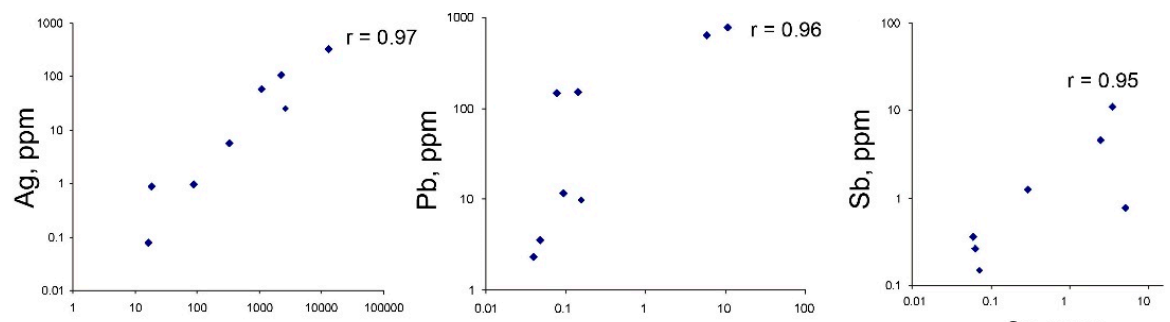

$\mathrm{Cu}, \mathrm{ppm}$
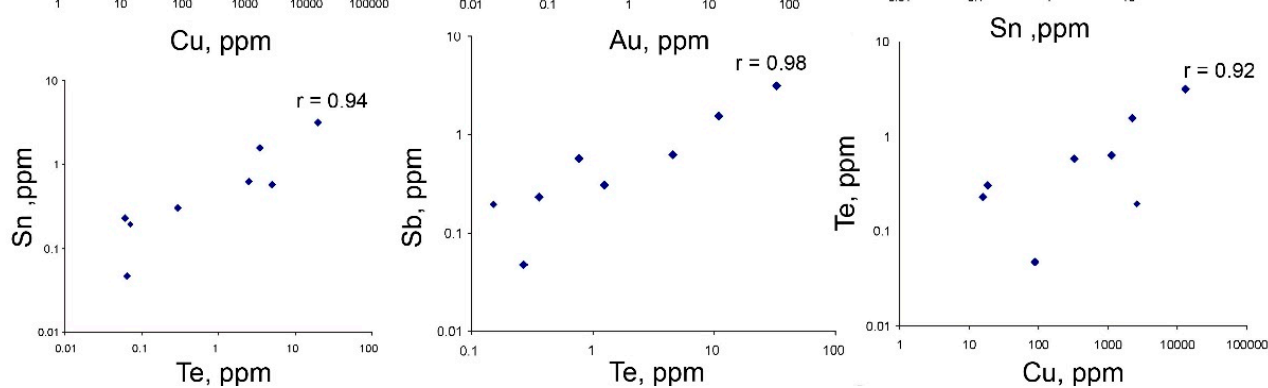

Figure 9. Log-log plots for selected trace elements in clastic fine-crystalline pyrite (ppm). 

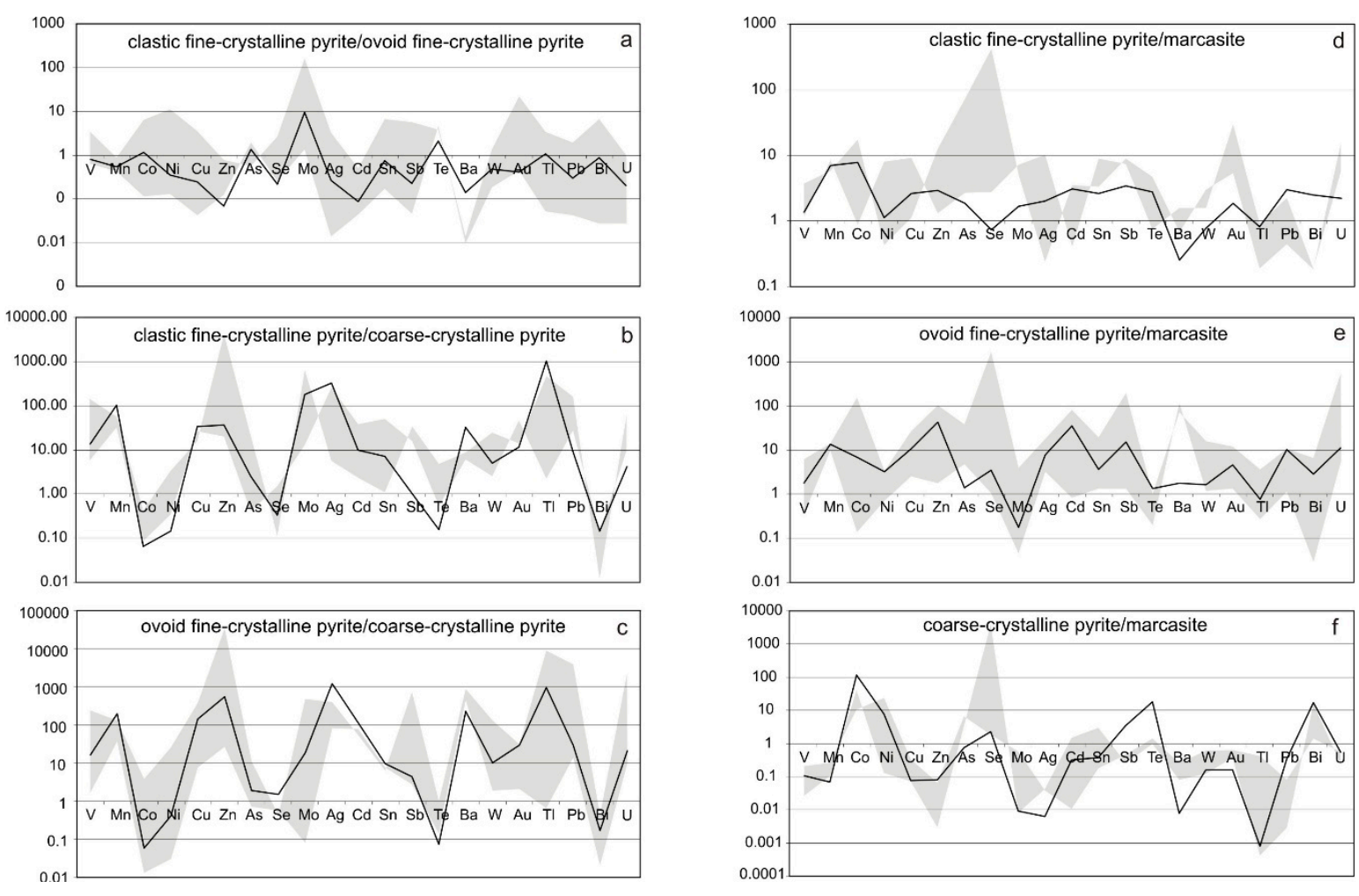

Figure 10. Ratios of average trace element contents for pairs of major sulfide types: (a) clastic fine-crystalline pyrite/ovoid fine-crystalline pyrite; (b) clastic fine-crystalline pyrite/coarse-crystalline pyrite; (c) ovoid fine-crystalline pyrite/coarse-crystalline pyrite; (d) clastic fine-crystalline pyrite/marcasite; (e) ovoid fine-crystalline pyrite; (f) coarse-crystalline pyrite/marcasite. The shaded area corresponds to variations in maximum and minimum ratios of trace element contents.

The coarse-crystalline pyrite has a moderate median content ( $>100 \mathrm{ppm})$ of $\mathrm{Co}$, low median contents ( $>10 \mathrm{ppm})$ of $\mathrm{Ni}, \mathrm{Cu}, \mathrm{As}$ and Se, and very low $(<10 \mathrm{ppm})$ contents of other trace elements (Table 5). In coarse-crystalline pyrite, $\mathrm{V}$ and $\mathrm{Ni}$ are correlated with $\mathrm{W} ; \mathrm{Mn}$ has correlations with As, Ag, $\mathrm{Au}$ and $\mathrm{Pb}$ (Supplementary Materials, Figure 11). Copper and $\mathrm{Zn}$ are mutually correlated and are also correlated with $\mathrm{Tl}, \mathrm{Zn}, \mathrm{Mo}, \mathrm{Ag}$, Bi and U. Arsenic has correlations with $\mathrm{Mn}, \mathrm{Au}$ and $\mathrm{Pb}$. Molybdenum, as well as $\mathrm{Ag}$, is correlated with $\mathrm{Cu}, \mathrm{Zn}, \mathrm{Ag}, \mathrm{Tl}, \mathrm{Bi}$ and $\mathrm{U}$. Tin is only correlated with $\mathrm{W}$, whereas $\mathrm{Sb}$ has correlation with $\mathrm{Pb}$. Thallium and Bi are correlated with $\mathrm{Cu}, \mathrm{Zn}, \mathrm{Mo}, \mathrm{Ag}$, Bi and $\mathrm{U}$. Lead and $\mathrm{U}$ have correlations with each other and with $\mathrm{Mn}, \mathrm{As}, \mathrm{Ag}, \mathrm{Sb}$ and $\mathrm{Au}$. Cobalt, $\mathrm{Se}$, Te and Cd have no correlations with other elements. Relative to clastic pyrite, coarse-crystalline pyrite is enriched in $\mathrm{Co}$, $\mathrm{Ni}$, Te and Se and depleted in almost in all trace elements (V, Mn, Cu, Zn, As, Se, Mo, Ag, Cd, Sn, Sb, $\mathrm{W}, \mathrm{Au}, \mathrm{Tl}, \mathrm{Pb}, \mathrm{Bi}, \mathrm{U}$ ) (Figure 10b,c).

Marcasite has a moderate median content $(>100 \mathrm{ppm})$ of $\mathrm{Cu}$, low median contents ( $>10 \mathrm{ppm})$ of $\mathrm{Mn}, \mathrm{Zn}, \mathrm{As}, \mathrm{Se}, \mathrm{Mo}, \mathrm{Tl}$, and $\mathrm{Pb}$, and very low median contents $(<10 \mathrm{ppm})$ of other elements. The compositions of clastic and crystalline marcasite are indistinguishable. Marcasite is generally depleted in trace elements relative to ovoid and clastic fine-crystalline pyrite and enriched in trace elements relative to coarser-crystalline pyrite (Figure 10d-f). In marcasite, Co is closely associated with $\mathrm{Bi}$ and $\mathrm{Te}$, as well as $\mathrm{Ni}, \mathrm{Au}, \mathrm{Se}, \mathrm{Cu}, \mathrm{Mo}, \mathrm{Ag}$ and $\mathrm{Sb}$ (Supplementary Materials). Nickel is correlated with all these elements except for Ag. Copper and Se are correlated with all above elements except for $\mathrm{Mo}$ and $\mathrm{Ag}(\mathrm{Cu})$ and $\mathrm{Mo}(\mathrm{Se})$. Zinc is correlated with $\mathrm{Cd}$ and $\mathrm{Sn}$. Arsenic has negative correlation with Tl. Silver is correlated with $\mathrm{Co}, \mathrm{Se}, \mathrm{Te}, \mathrm{Au}, \mathrm{Bi}$ and $\mathrm{U}$. Tin is associated with $\mathrm{Zn}$ and $\mathrm{Cd}$, as well as with $\mathrm{Se}, \mathrm{Au}$ and $\mathrm{U}$. Te has high correlation with $\mathrm{Bi}$ and $\mathrm{Co}$ and weaker correlations with $\mathrm{Ni}, \mathrm{Cu}, \mathrm{Se}, \mathrm{Mo}, \mathrm{Ag}$, $\mathrm{Sb}$ and $\mathrm{Au}$. W is only correlated with $\mathrm{Pb}$. Uranium is correlated with Se, Ag and $\mathrm{Sn}$. 

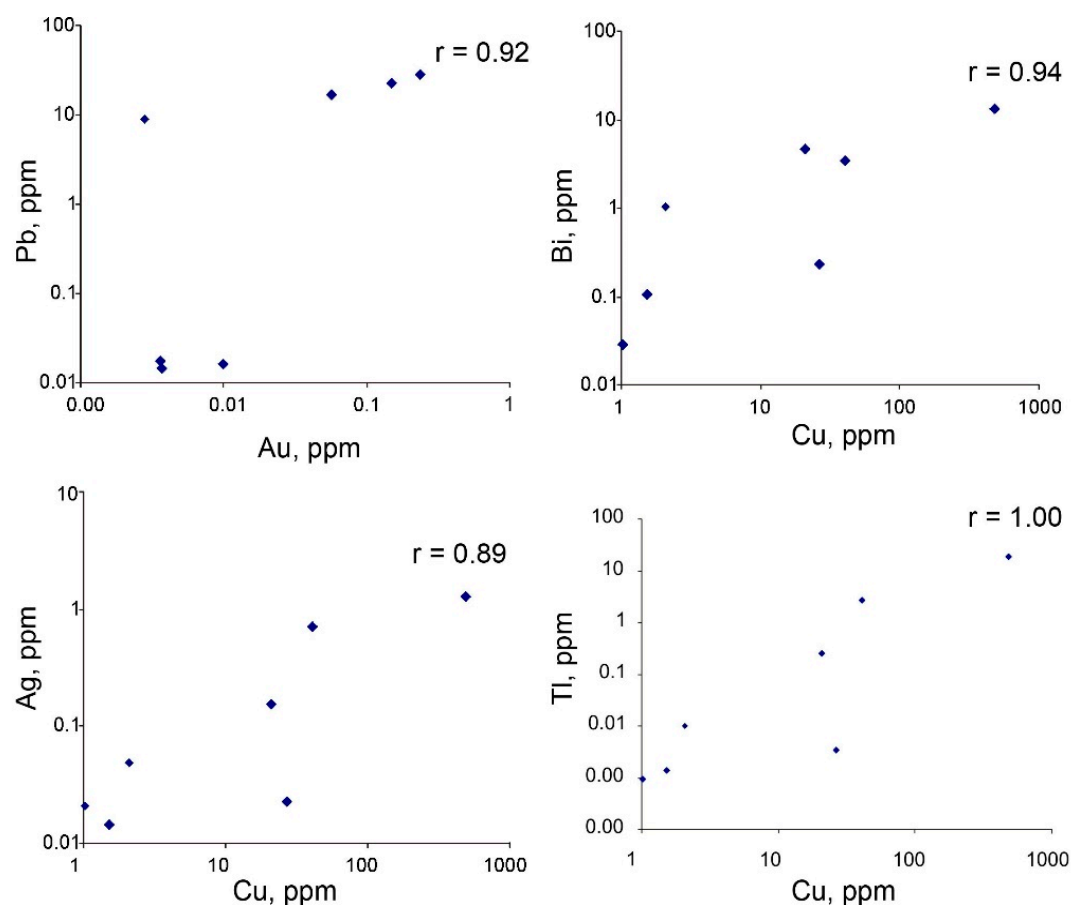

Figure 11. Log-log plots for selected trace elements in coarse-crystalline pyrite (ppm).

Reniform chalcopyrite is characterized by moderate median contents ( $>100 \mathrm{ppm}$ ) of $\mathrm{Zn}, \mathrm{As}$, and $\mathrm{Pb}$, a low median content $(>10 \mathrm{ppm})$ of $\mathrm{Ag}$, and very low median contents $(<10 \mathrm{ppm})$ of other elements (Table 5). In reniform chalcopyrite, $\mathrm{Mn}$ is positively correlated with $\mathrm{W}$ and $\mathrm{Tl}$ and is negatively correlated with Mo (Supplementary Materials, Figure 12). Zinc is negatively correlated with $\mathrm{Cd}$ and is positively correlated with $\mathrm{W}$ and $\mathrm{Tl}$, whereas $\mathrm{W}$ is positively correlated with $\mathrm{Tl}, \mathrm{Zn}, \mathrm{Pb}$ and $\mathrm{Mn}$. Arsenic has positive correlation with Se, Mo and Ag. Molybdenum is correlated with As, Se and $\mathrm{Sb}$ and has negative correlation with $\mathrm{Mn}$. High correlations exhibit some couples of elements: $\mathrm{Sn}-\mathrm{Pb}, \mathrm{Sb}-\mathrm{Mo}, \mathrm{Te}-\mathrm{U}$ and $\mathrm{Au}-\mathrm{Pb}$. Clastic crystalline chalcopyrite is more enriched in $\mathrm{Ag}(>100 \mathrm{ppm})$ and $\mathrm{V}, \mathrm{Mo}, \mathrm{Sb}$, and $\mathrm{W}$ (>10 ppm) and, in general, in most trace elements relative to the reniform variety (Table 5).
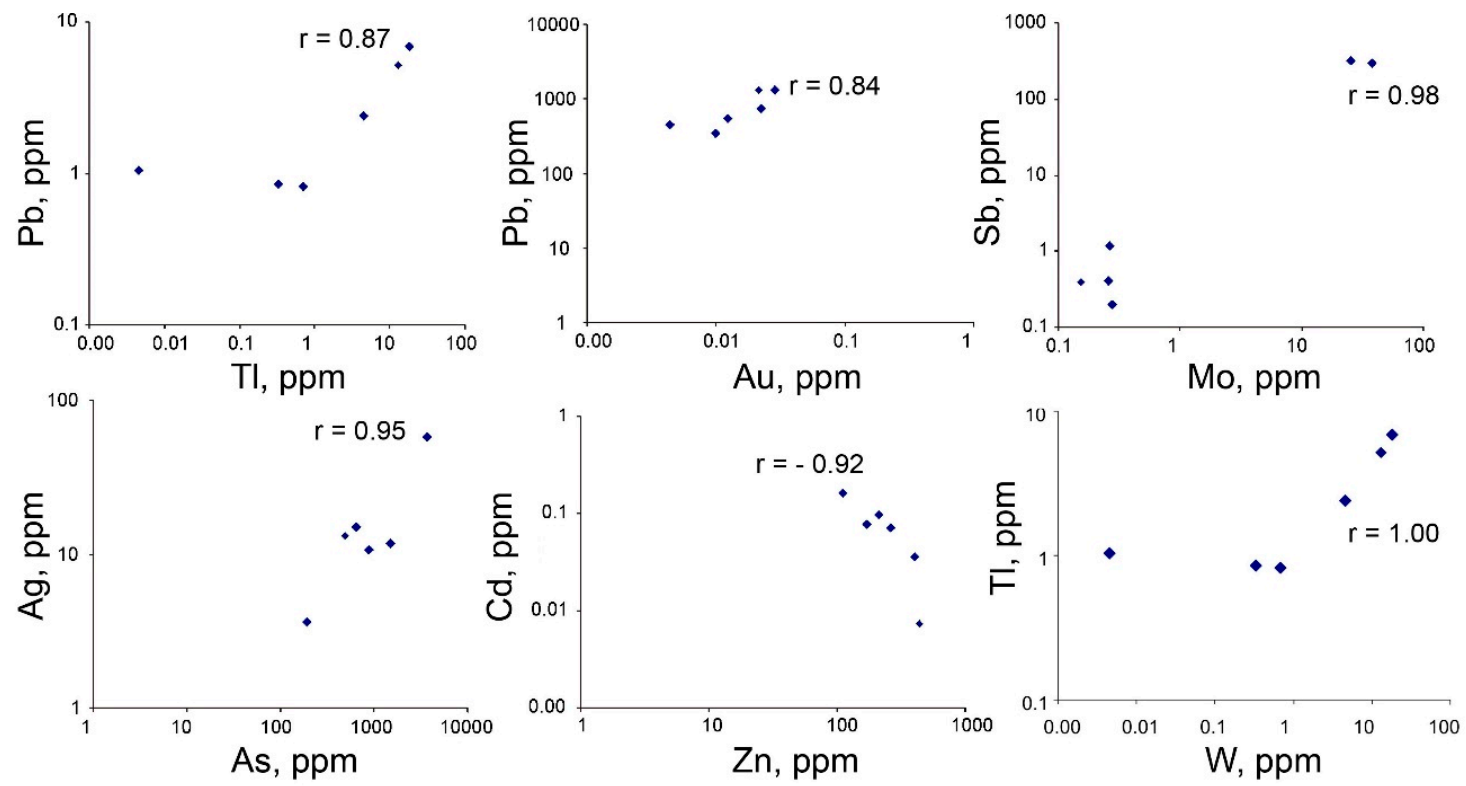

Figure 12. Log-log plots for selected trace elements in reniform chalcopyrite (ppm). 


\subsection{Trace Element Zoning in Nodular Pyrite}

The trace element zoning in coarse-crystalline pyrite was determined for a nodular pyrite aggregate (hereafter, "nodule" for the sake of simplicity) showing two distinct concentric zones under an optical microscope (Figure 4c). LA-ICP-MS compositional maps were acquired for $\mathrm{Na}, \mathrm{Mg}$, Al, Si, P, S, K, Ca, Ti, V, Cr, Mn, Fe, Co, Ni, Cu, Zn, Ga, Ge, As, Se, Sr, Mo, Ag, Cd, In, Sn, Sb, Te, Ba, $\mathrm{W}, \mathrm{Au}, \mathrm{Hg}, \mathrm{Tl}, \mathrm{Pb}$ and $\mathrm{Bi}$. The maps for the most representative major and trace elements $(\mathrm{Fe}, \mathrm{S}, \mathrm{Co}$, $\mathrm{Bi}, \mathrm{Mo}, \mathrm{Te}, \mathrm{U}, \mathrm{Cu}, \mathrm{Ag}$, As, Pb, Tl, Zn, In, Ge, Cd, Sb) are shown in Figure 13. The maps for the other elements are not shown, because they are related to non-sulfide minerals. Some trace elements (Ni, Ga, $\mathrm{Se}, \mathrm{Sn}, \mathrm{W}, \mathrm{Au}, \mathrm{Hg}$ ) had very low contents and showed no zoning inside the nodule (Figure 13).
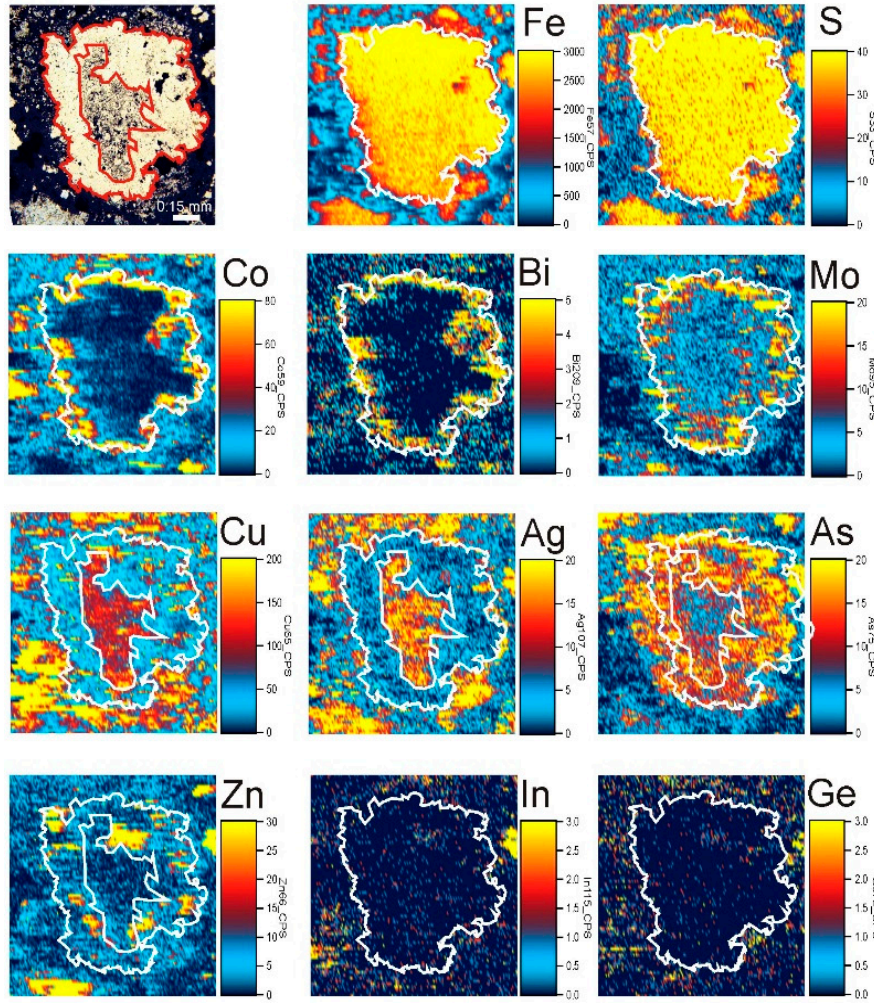
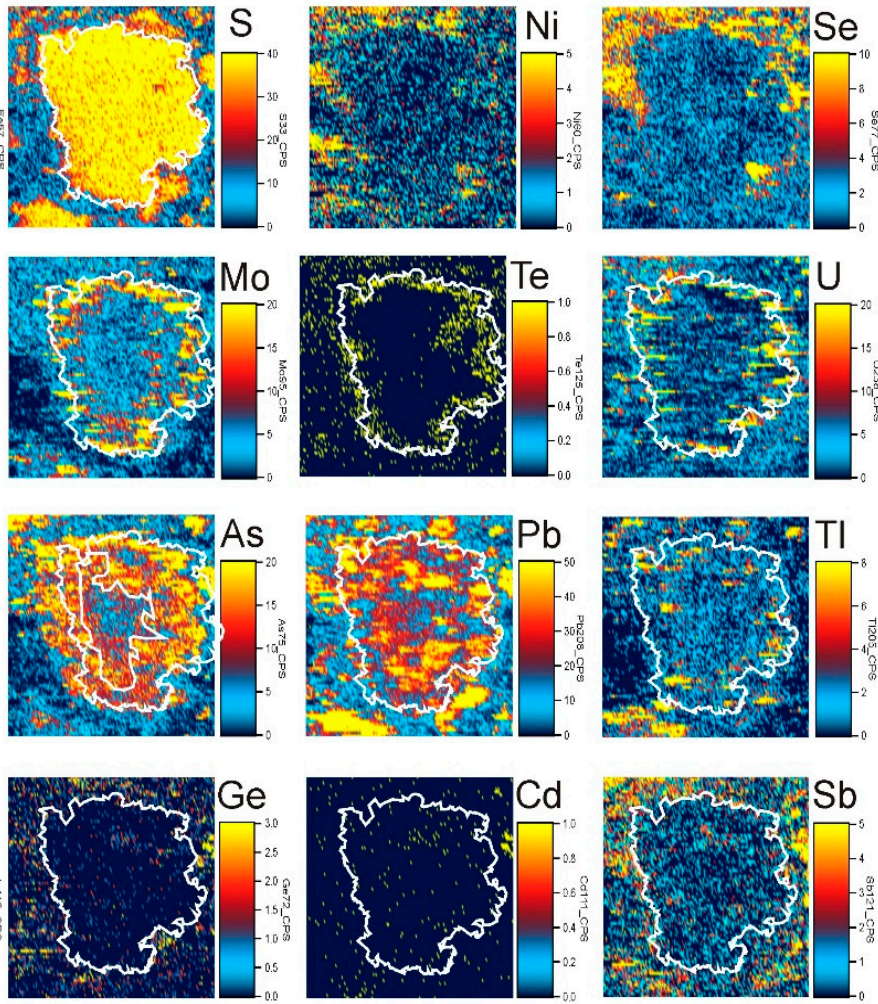

Figure 13. LA-ICP-MS trace element pattern of a nodular pyrite aggregate. The Ni and Se maps are shown as example of no zoning inside the nodule.

The two major elements of the nodule (Fe and S) are uniformly distributed within the zones (Figure 13). The more compact external domain contains a fine outer zone, which is enriched in Co, $\mathrm{Bi}, \mathrm{Mo}, \mathrm{Te}$, and U. Copper is mostly concentrated in the central domain of the nodule, as well as in neighbor clasts of porous pyrite. The distribution of Ag mostly mimics that of $\mathrm{Cu}$; an additional small Ag-rich area occur in the right part of the nodule and in numerous areas outside it, where they correspond to increased concentrations of $\mathrm{Pb}$ in porous pyrite clasts. The lowest Ag contents within the nodule, which are expressed by dark-blue spots in its external portion, correspond to a fine discontinuous marcasite-rich zone (Table 5). Arsenic is typically confined to the outer crystalline part of the nodule. Lead exhibits a patchy distribution inside the crystalline part of the nodule, which partially matches those of $\mathrm{As}$ and $\mathrm{Ag}$; the highest $\mathrm{Pb}$ contents are observed in fragments of clastic porous pyrite outside the nodule, where also the highest Ag contents are found. Thallium is enriched in small pyrite grains and aggregates of porous pyrite outside the nodule, where it is sometimes associated with high $\mathrm{Pb}$ and $\mathrm{As}$, and in some $\mathrm{Zn}$-rich areas inside the nodule. The bright $\mathrm{Zn}$ spots mark areas saturated with sphalerite microinclusions. One Zn-rich area to the right of the nodule coincides with increased contents of In, Ge, Cd and Sb. 


\section{Discussion}

\subsection{Textures, Structures, and Mineralogy of Sulfide Breccias}

In the Semenov-3 sulfide breccias, the sulfide clasts have only occasional contacts, lack any sorting or bedding and show a variety of textures typical of primary hydrothermal ores. According to the morphological analysis of the massive sulfide bodies developed for the Uralian VHMS deposits [47,48], these features are characteristic of proximal sulfide breccias, which have been transported for some distance from the place of erosion. In well-preserved sulfide mounds from the Urals (e.g., Yaman-Kasy, Saf'yanovskoe, Dergamysh VHMS deposits [3,49]), these breccias occur at a distance of at least $25 \mathrm{~m}$ from the center of the interpreted sulfide mounds.

Pyrite and marcasite in the sulfide breccias represent a variety of morphological aggregates. Their clasts contain occasional inclusions of chalcopyrite, sphalerite, and barite. Their clastic nature is mainly indicated by cutting-off of their textural pattern and zoning, as well as by the similarity of their internal structure with that of larger sulfide clasts (Figure 3). The colloform, radial, and concentric-zonal structures and the mineralogical composition are similar to those of colloform, porous, and massive Ba-rich sulfides from the adjacent Semenov-1 hydrothermal field [4].

The sulfide breccias from the Semenov-3 hydrothermal field underwent a series of lithification processes, involving congelation, recrystallization, crystallization, compaction and cementation (cf. [17]). The presence of some indicative morphological varieties of pyrite is evidence for their diagenetic origin (Figure 14). In sedimentary rocks, framboidal pyrite is a typical product of early diagenesis [50-52]. The next stage of diagenetic process, when framboids join together and are being recrystallized, is most likely marked by the formation of ovoid fine-crystalline (former framboidal) pyrite aggregates and by the replacement of framboids by crystalline pyrite (Figure 14). Nodular pyrite, which is characterized by a porous core and a polycrystalline exterior, and subhedral to euhedral coarse-crystalline pyrite were formed during late diagenesis (Figure 14). Their authigenic origin is supported by the larger size of individual crystals relative to clastic fine-crystalline pyrite, the euhedral to subhedral morphology, fine zoning visible after etching, and the presence of numerous inclusions of other minerals (Figures 3a, 4 and 5). In fossil VHMS deposits, the pyrite nodules are typical of ore-controlling fine-clastic (pelitic) sediments around massive sulfide bodies and have not been described in sulfide breccias yet $[18,19,53,54]$.

The diverse morphology and mineral assemblages of accessory minerals the Semenov-3 sulfide breccias are also indicative of their clastic and authigenic origin. Subhedral to euhedral isometric chalcopyrite crystals in the breccia matrix and altered volcanic clasts could represent the fragments of $\mathrm{Cu}$-rich stringer-disseminated mineralization from high-temperature feeder zones of the sulfide mound (cf. [28]). Chalcopyrite inclusions in pyrite-marcasite clasts are most likely of primary hydrothermal origin similar to numerous chalcopyrite inclusions in Fe-rich massive sulfides from the adjacent Semenov-1 hydrothermal field [4]. The acicular chalcopyrite crystals and zoned crystalline intergrowths with sphalerite and bornite resemble the fragments of black smoker chimneys [3,55-57]. Their high-temperature origin is also supported by chemistry of crystalline chalcopyrite (see below). The finding of clastic $\mathrm{Cu}$ - and $\mathrm{Zn}$-rich mineral assemblages in sulfide breccias indicates the erosion of primary $\mathrm{Cu}-\mathrm{Zn}$ sulfides within the Semenov-3 hydrothermal field, including a black smoker complex, which have not been discovered yet. The resorbed margins of many chalcopyrite crystals (Figure 6a-c) are evidence of their dissolution during sedimentation. Dissolution of primary hydrothermal chalcopyrite results in the formation of authigenic one from $\mathrm{Cu}$-bearing diagenetic fluids. In contrast to primary hydrothermal chalcopyrite, the authigenic one is observed as inclusions in authigenic coarse-crystalline pyrite, anhedral aggregates in the breccia matrix, and pseudomorphic reniform aggregates after radial marcasite (Figure 14). 


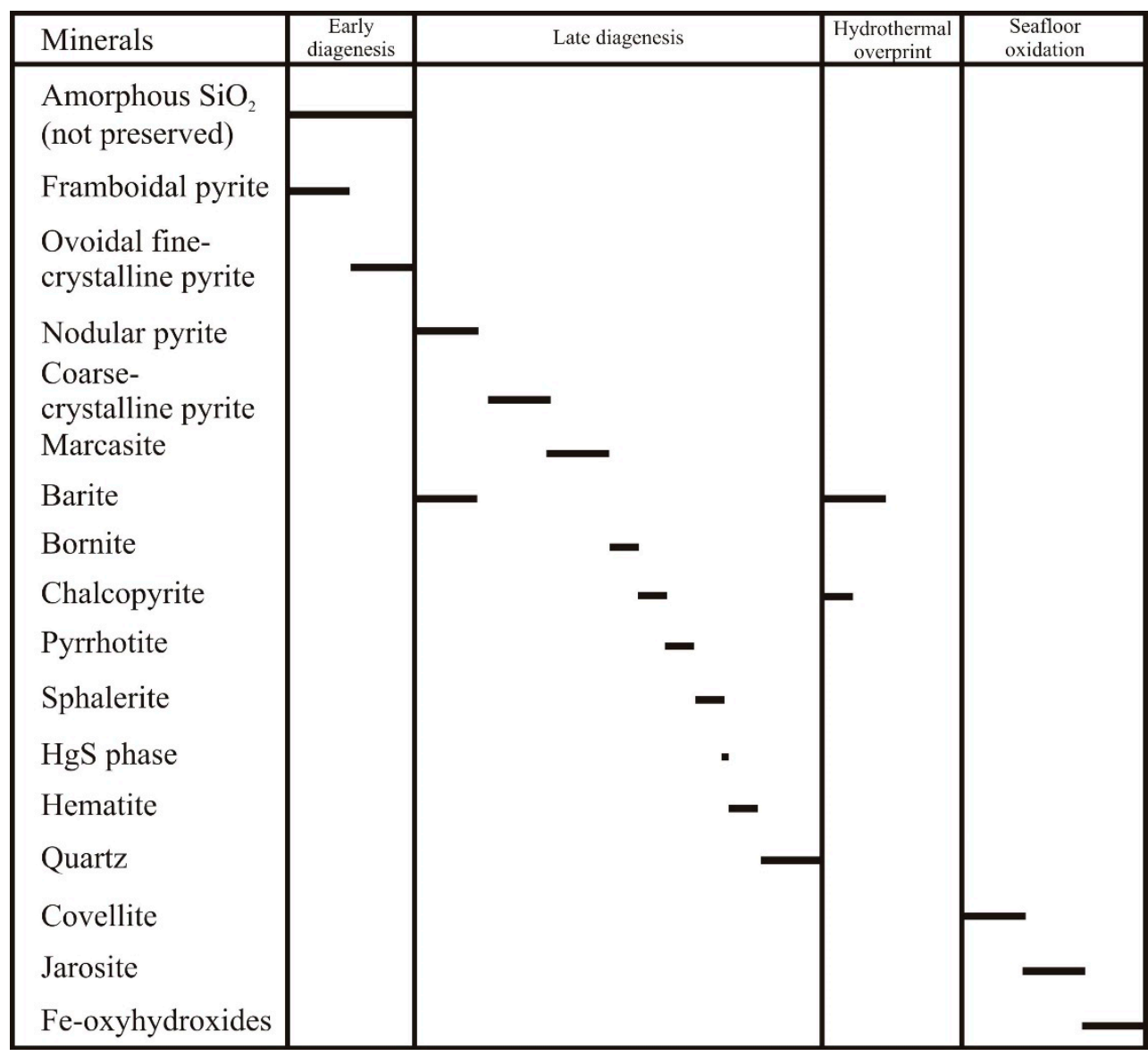

Figure 14. Paragenetic sequence of diagenetic mineral formation in sulfide breccias from the Semenov-3 hydrothermal field.

Similar to chalcopyrite, sphalerite and pyrrhotite associated with hydrothermal chalcopyrite are hydrothermal in origin, whereas those found in authigenic coarse-crystalline pyrite, are authigenic (Figure 14). Euhedral morphology of the hematite crystals, its presence in the breccia cement and assemblage with quartz most likely indicate its authigenic origin. The fact that crystalline hematite is never in contact with authigenic chalcopyrite, bornite, pyrrhotite and sphalerite indicates its probable crystallization during late diagenesis (Figure 14).

Barite, which is associated with pyrite-marcasite clasts, is most likely hydrothermal in origin, similar to barite from Ba-rich massive sulfides from the adjacent Semenov-1 hydrothermal field [4]. The well-formed barite laths in the breccia matrix likely formed during early diagenesis were further replaced by late diagenetic coarse-crystalline pyrite (Figures $4 \mathrm{~d}$ and 14 ). Finally, the previously studied druses of large euhedral barite crystals with formation temperatures of $265-335{ }^{\circ} \mathrm{C}$ indicate a late high-temperature hydrothermal overprint [46].

Thus, the diagenetic processes occurred within the sulfide breccias from the Semenov-3 hydrothermal field are responsible for the formation of more diverse authigenic mineralization with various morphological types of pyrite and marcasite, new generations of barite, chalcopyrite, pyrrhotite, sphalerite and bornite, newly formed $\mathrm{HgS}$ phase, hematite and quartz.

\subsection{Mineral Geochemistry}

The generally low contents of valuable trace elements of the Semenov-3 sulfide breccias are consistent with the relatively "clean" compositions of individual sulfides. The highest contents of trace elements are detected in authigenic ovoid fine-crystalline (former framboidal) pyrite (Table 5). 
This is similar to the enrichment of early diagenetic framboids described in VHMS deposits of the Urals (e.g., Saf'yanovskoe and Yaman-Kasy) [54]. The enrichment of early diagenetic pyrite from these deposits is explained by its precipitation from diagenetic fluids rich in trace elements because of the dissolution of small clasts of primary hydrothermal minerals. The low-temperature fast growth during early diagenesis allows the trace elements to be incorporated into pyrite in solid solution or as very small $(<5 \mu \mathrm{m})$ inclusions [58].

Similar to late diagenetic euhedral pyrite crystals from fine-clastic sediments of the Uralian VHMS deposits [53,54], the late diagenetic coarse-crystalline pyrite is depleted of trace elements in comparison with early diagenetic pyrite, except for a relative enrichment in Co and Ni (Table 5, Figure 8). The depletion of late diagenetic coarse-crystalline pyrite indicates its crystallization from diagenetic fluids depleted in trace elements $[53,54]$ at relatively higher temperatures, which allowed the trace elements to be partitioned into separate sulfide phase [59] such as chalcopyrite and sphalerite associated with the Semenov-3 coarse-crystalline pyrite. The enrichment of coarse-crystalline pyrite in $\mathrm{Co}$ and Ni may thus reflect higher crystallization temperatures (cf. [2]).

The correlation of $\mathrm{Ag}, \mathrm{Sb}, \mathrm{Sn}, \mathrm{Ni}$ and $\mathrm{Te}$ with $\mathrm{Cu}$ in clastic fine-crystalline pyrite suggests their incorporation in chalcopyrite inclusions. The absence of correlation between $\mathrm{Se}$ and $\mathrm{Cu}$ in this pyrite type suggests that Se could be pyrite-hosted. In ovoid fine-crystalline pyrite, the positive correlation between $\mathrm{Cu}$ and a number of elements $(\mathrm{Au}, \mathrm{Sb}, \mathrm{Sn}, \mathrm{Co}, \mathrm{Ni}, \mathrm{Se})$ again indicates their likely association with chalcopyrite, whereas the negative correlation with As indicates that As is pyrite-hosted. Zinc and $\mathrm{Cd}$ can be ascribed to the presence of sphalerite inclusions. The association of $\mathrm{Au}$ with $\mathrm{Pb}$ in clastic fine-crystalline and authigenic coarse-crystalline pyrite, marcasite and chalcopyrite suggests that $\mathrm{Au}$ in sulfide breccias from the Semenov-3 hydrothermal field is preferentially associated with nanoinclusions of galena. Preferential partitioning of trace metals including $\mathrm{Pb}, \mathrm{Bi}, \mathrm{Sb}, \mathrm{Au}, \mathrm{Ag}, \mathrm{Ni}, \mathrm{Te}, \mathrm{Hg}$, and As into nanoparticles less than $20 \mathrm{~nm}$ in size has recently been reported from various hydrothermal, diagenetic and groundwater systems dominated by reducing conditions [59].

The correlation of Ag, As and Se in authigenic chalcopyrite suggests their combined isomorphic substitution for $\mathrm{Cu}, \mathrm{Fe}^{3+}$ and $\mathrm{S}$, respectively [60]. The local anomalies of $\mathrm{As}$ and $\mathrm{Sb}$ and positive correlation between these two elements reflect the presence of tetrahedrite-tennantite nanoinclusions. $\mathrm{The} \mathrm{Pb}-\mathrm{Tl}, \mathrm{Tl}-\mathrm{W}$ and $\mathrm{Pb}-\mathrm{Au}$ correlations again suggest the presence of $\mathrm{Tl}-\mathrm{W}$-bearing galena-native gold assemblage. The negative correlation between $\mathrm{Zn}$ and $\mathrm{Cd}$ indicates that $\mathrm{Cd}$ is not hosted in sphalerite. The absence of any correlation of $\mathrm{Cd}$ with other elements suggests its presence in native or sulfide form. Native cadmium, for instance, was reported from the Logatchev-1 hydrothermal field, MAR [61]. Greenockite (CdS) inclusions were found in chalcopyrite of black smoker chimneys from the Yaman-Kasy VHMS deposit, Southern Urals [2].

The enrichment of crystalline chalcopyrite in trace elements, especially Se, is considered the evidence for high- $T$ and reducing conditions $[2,62,63]$. This is another proof of its high-temperature hydrothermal origin, most likely, within the black smoker complex. In contrast, reniform chalcopyrite, like authigenic coarse-crystalline pyrite, is depleted in most trace elements.

The diagenetic processes thus resulted in redistribution (remobilization) of valuable components between primary hydrothermal and authigenic minerals. The early diagenetic pyrite is enriched in trace elements relative to late diagenetic one indicating exhausting early to late diagenetic pore fluids. The lower trace element composition of late diagenetic chalcopyrite relative to primary hydrothermal one reflects the depletion of lower-temperature diagenetic pore fluids in trace elements in comparison with high-temperature hydrothermal fluids.

\subsection{Trace Element Zoning of the Pyrite Nodule}

The association of $\mathrm{Cu}$ with $\mathrm{Ag}$ in the porous core of the authigenic pyrite nodule may reflect the entrapment of ultramicroscopic inclusions of primary hydrothermal Ag-bearing chalcopyrite (up to $1106 \mathrm{ppm} \mathrm{Ag,} \mathrm{Table} \mathrm{5).} \mathrm{Arsenic,} \mathrm{which} \mathrm{is} \mathrm{concentrated} \mathrm{in} \mathrm{the} \mathrm{more} \mathrm{compact} \mathrm{outer} \mathrm{rim} \mathrm{of} \mathrm{the}$ pyrite nodule, is most probably isomorphically incorporated in pyrite. Association of $\mathrm{Tl}$ with $\mathrm{Ag}$ 
and $\mathrm{Pb}$ outside the pyrite nodule may indicate incorporation of $\mathrm{Tl}$ in submicroscopic galena (cf. [64]). The association of $\mathrm{Zn}$ with $\mathrm{In}, \mathrm{Ge}, \mathrm{Cd}$, Sb and, locally, Tl inside the nodule suggests that these elements are hosted in sphalerite inclusions. The association between $\mathrm{Tl}$ and $\mathrm{Zn}$ has previously been found in VHMS, Carlin-type gold, thallium and $\mathrm{Zn}-\mathrm{Pb}-\mathrm{Ag}$ deposits [65] and references therein.

In the absence of detailed descriptions of similar nodules from oceanic hydrothermal sulfide fields, we have compared the pyrite nodule from the Semenov-3 breccias with analogues from fossil VHMS deposits (Bracemac-McLeod deposit in Canada, Lahanos deposit in Turkey, and Saf'yanovka and Yubileynoe deposits in the Urals), in which Fe disulfide nodules have been found in illite-hematite gossanites (cf. [66]), tuffites and sedimentary host rocks [18,19,65,67]. The main features of pyrite nodules in these deposits are summarized in Table 6. Despite the different host rocks and types of mineral inclusions, the nodules from all localities are similar in morphology exhibiting a central domain with inclusions of both ore and non-opaque minerals (described as "poikilitic" pyrite by some authors $[18,19,67])$, an intermediate crystalline zone, and a fine crystalline rim. Locally, the rim is made of marcasite, as in the Lahanos deposit [18]. This morphological similarity points to a common diagenetic process, which may occur in sediments composed of various-sized clasts, from coarse-clastic breccias (Semenov-3 field) to fine clastic sediments.

In both fossil and present-day examples, the pyrite nodules exhibit a compositional differentiation between the different zones. It was recently shown $[53,54,68]$ that the composition of the associated sedimentary rocks and of the massive sulfide clasts, as well as their size, is responsible for the formation of specific authigenic mineral assemblages. In contrast to the mineralogically more complex Uralian examples, the simple pyrite-dominated composition of primary hydrothermal ores from the Semenov-3 hydrothermal field and the coarse size of the sediments resulted in formation of monotonous authigenic minerals. This is also reflected in the geochemical features of the pyrite nodules. Fossil pyrite nodules are enriched in most trace elements in the central porous zone because of the more diverse mineral composition of clasts of primary massive sulfide ores, which were dissolved during halmyrolysis $[18,19,67]$. The composition of authigenic pyrite nodules may thus be a proxy for the composition of the initial massive sulfide bodies. 
Table 6. Comparative features of sulfide nodules from the Semenov-3 hydrothermal field, Mid-Atlantic Ridge (MAR), and fossil volcanic-hosted massive sulfide (VHMS) deposits.

\begin{tabular}{|c|c|c|c|c|c|}
\hline Objects & Semenov-3 (This Study) & Bracemac-Mcleod [65] & Lahanos [18] & Saf'yanovka [19] & Yubileynoe [67] \\
\hline Host Rocks & Basalts & Rhyolites, Andesites, Basalts & Dacites and Rhyodacites & Rhyolites & Basalts and Rhyolites \\
\hline Nodule-Hosted Rocks & Sulfide Breccias & Key Tuffite Horizon & Illite-Hematite Gossanites & Black Shales & Siliceous Rocks \\
\hline Sulfide nodules & $\begin{array}{l}\text { Pyrite nodule composed of } \\
\text { a porous center with visible } \\
\text { inclusions of quartz and } \\
\text { barite and a polycrystalline } \\
\text { rim with visible inclusions } \\
\text { of sphalerite, chalcopyrite } \\
\text { and pyrrhotite }\end{array}$ & $\begin{array}{l}\text { Pyrite nodule composed of a } \\
\text { porous center (Py I) with } \\
\text { inclusions of sphalerite and } \\
\text { chalcopyrite, which is } \\
\text { overgrown by crystalline pyrite } \\
\text { (Py II and Py V) }\end{array}$ & $\begin{array}{l}\text { Marcasite-pyrite nodule } \\
\text { composed of a porous pyrite } \\
\text { center with inclusions of illite, } \\
\text { barite, apatite, galena, aikinite, } \\
\text { bornite, tennantite-tetrahedrite, } \\
\text { hematite and rutile, which is } \\
\text { overgrown by crystalline pyrite } \\
\text { and marcasite }\end{array}$ & $\begin{array}{l}\text { Pyrite nodule composed } \\
\text { of a porous center with } \\
\text { inclusions of chlorite, } \\
\text { micas, sphalerite and } \\
\text { chalcopyrite and a rim of } \\
\text { crystalline pyrite with } \\
\text { inclusions of galena }\end{array}$ & $\begin{array}{l}\text { Pyrite nodule composed } \\
\text { of a porous center with } \\
\text { inclusions of quartz, } \\
\text { chlorite, plagioclase, mica, } \\
\text { galena, native gold and } \\
\text { Bi-, Ag-, Au-, Hg- and } \\
\text { Pb-tellurides }\end{array}$ \\
\hline $\begin{array}{l}\text { Trace elements enriched } \\
\text { in the porous central zone }\end{array}$ & $\mathrm{Cu}, \mathrm{Ag}$ & $\begin{array}{c}\mathrm{Cu} \text { and } \mathrm{Ni} \text {; locally, } \mathrm{As}, \mathrm{Se}, \mathrm{Au}, \\
\mathrm{Ag}, \mathrm{Pb}, \mathrm{Zn}, \mathrm{Sb}, \mathrm{Cd}, \mathrm{Sn}\end{array}$ & $\begin{array}{l}\mathrm{Cu}, \mathrm{Pb}, \mathrm{Ag}, \mathrm{Co}, \mathrm{Ni} \text { and } \mathrm{Hg} \\
\text { locally, } \mathrm{As} \text { and } \mathrm{Sb}\end{array}$ & $\begin{array}{l}\mathrm{Cu}, \mathrm{Zn}, \mathrm{Co}, \mathrm{Ni}, \mathrm{Mn}, \mathrm{Tl}, \mathrm{Sb} \\
\mathrm{Au}, \mathrm{Se}, \mathrm{Bi}, \mathrm{Cd}, \mathrm{In}, \mathrm{Sn}\end{array}$ & $\begin{array}{c}\mathrm{Cu}, \mathrm{Zn}, \mathrm{Pb}, \mathrm{Sb}, \mathrm{Bi}, \mathrm{As}, \mathrm{Au}, \\
\mathrm{Ag}, \mathrm{Te}, \mathrm{Hg}, \mathrm{Co}, \mathrm{Ni}, \mathrm{As}\end{array}$ \\
\hline $\begin{array}{l}\text { Trace elements enriched } \\
\text { in the intermediate } \\
\text { crystalline zone }\end{array}$ & As; locally, $\mathrm{Pb}$ and $\mathrm{Zn}$ & Co, As and $\mathrm{Tl}$; locally, Se & $\mathrm{Pb}$ and $\mathrm{Cu}$; locally, $\mathrm{Ag}$ and $\mathrm{Ni}$ & $\mathrm{Pb}, \mathrm{Cu}, \mathrm{As}, \mathrm{Ag}, \mathrm{Mo}, \mathrm{Ge}$ & $\mathrm{Ni}$, As \\
\hline $\begin{array}{l}\text { Trace elements enriched } \\
\text { in the crystalline rim }\end{array}$ & $\mathrm{Co}, \mathrm{Bi}, \mathrm{Mo}, \mathrm{Te}, \mathrm{U}$ & $\mathrm{Tl}$; locally, Ni, Se & $\mathrm{Ni}, \mathrm{In}, \mathrm{As}, \mathrm{Sb}, \mathrm{Cd}, \mathrm{In}, \mathrm{Mo}$ & As, Ag & $\mathrm{Au}, \mathrm{Ag}, \mathrm{Sb}, \mathrm{Bi}, \mathrm{Cu}, \mathrm{Zn}, \mathrm{Hg}$ \\
\hline
\end{tabular}




\subsection{Possible Exploration Guidelines}

The sulfide breccias from the Semenov-3 hydrothermal field are mostly composed of Fe disulfides and, thus, are of little economic interest. Among valuable minerals, however, they contain chalcopyrite, bornite, covellite, and sphalerite, some of which ( $\mathrm{Cu}-\mathrm{Fe}$ and $\mathrm{Cu}$ sulfides) occur mostly in the breccia cement rather than as inclusions in Fe disulfides, which would make them easier to separate during ore processing. The inactive state of the hydrothermal field makes it more suitable for potential mining, albeit this would require elaboration of effective techniques of extraction of valuable components from pyrite- and marcasite-rich ores. The effective leaching of pyrite-rich massive sulfides $(25.8-45.3 \mathrm{wt} \% \mathrm{Fe})$ from the TAG hydrothermal field, MAR, was recently shown in [69]. The finding of primary hydrothermal clasts of chalcopyrite and sphalerite in sulfide breccias from the Semenov-3 hydrothermal field indicates the presence of $\mathrm{Cu}-\mathrm{Zn}$ massive sulfides in this area.

The knowledge of accessory minerals and trace element contents of massive sulfides is important not only from the processing viewpoint, but also for the possible environmental hazard. In particular, the finding of $\mathrm{HgS}$ phase in the sulfide breccias from the Semenov-3 hydrothermal field was unexpected posing a question of potential environmental impact, since $\mathrm{Hg}$ is known to be one of most toxic heavy metals [70]. Among seafloor hydrothermal fields, $\mathrm{Hg}$ mineral (e.g., cinnabar) was identified in polymetallic massive sulfides from the JADE hydrothermal field in Okinawa Trough [71]. Although $\mathrm{Hg}$ sulfides are insoluble and stable [72], the lattice-bound mode of $\mathrm{Hg}$ occurrence in sulfides or sulfosalts (e.g., sphalerite, tennantite-tetrahedrite) is more dangerous due to their solubility. Mercury was detected in sphalerite (up to $1.0 \mathrm{wt} \%$ ), enargite (up to $0.15 \mathrm{wt} \%$ ), tennantite-tetrahedrite (up to $0.54 \mathrm{wt} \%$ ) and covellite (up to $0.02 \mathrm{wt} \%$ ) of hydrothermal precipitates from the Hook Ridge of the Bransfield Strait [73]. In the Uralian VHMS deposits, $\mathrm{Hg}$ is also mostly concentrated in sphalerite and, to a lesser extent, tennantite-tetrahedrite and native gold [74]. According to LA-ICP-MS analyses, sphalerite from the nearby Semenov-2 hydrothermal field contains 9 to $47 \mathrm{ppm} \mathrm{Hg}$ (in-house unpublished data). Thus, we can speculate that the source of $\mathrm{Hg}$ for authigenic $\mathrm{HgS}$ phase from the Semenov-3 hydrothermal field was primary $\mathrm{Hg}$-bearing sphalerite, although we do not exclude some contribution of $\mathrm{Hg}$ from possible nanoinclusions of tennantite-tetrahedrite or galena.

The geochemical analysis of pyrite, marcasite and chalcopyrite from the Semenov-3 sulfide breccias has revealed the different mode of occurrence of some trace elements, which means their different behavior during possible recovery. In particular, valuable components (e.g., $\mathrm{Cu}, \mathrm{Zn}, \mathrm{Pb}, \mathrm{Au}$ ), which occur as inclusions (even ultramicroscopic), can effectively be extracted due to galvanic couples (e.g., [69]), whereas lattice-bound elements (e.g., $\mathrm{Ag}$, $\mathrm{Te}, \mathrm{Se}$ ) would require additional efforts and costs for their recovery [75].

\section{Conclusions}

The sulfide breccias from the Semenov-3 hydrothermal field contain primary hydrothermal clasts of colloform, radial, porous and fine-crystalline pyrite-marcasite aggregates, isometric and acicular chalcopyrite crystals and zoned intergrowths of chalcopyrite with sphalerite and bornite, as well as barite crystals. The textural-structural features of the Semenov-3 breccias are characteristic of proximal breccias, which have been transported for relatively small $(\geq 25 \mathrm{~m})$ distance from the place of erosion. The presence of primary high-temperature chalcopyrite and associated sphalerite and pyrrhotite in altered volcanic clasts and in the cement indicates the deep erosion of primary $\mathrm{Cu}-\mathrm{Zn}$ sulfides within the Semenov-3 hydrothermal field.

The study of sulfide breccias from the Semenov-3 hydrothermal field showed that diagenesis played a key role in transformation of coarse-clastic sulfide sediments. Diagenetic transformation of sulfide clasts into a lithified rock has resulted in the formation of the following more diverse authigenic mineral assemblages: framboidal pyrite; ovoid fine-crystalline (former framboidal) pyrite; nodular pyrite; coarse-crystalline pyrite; zoned bornite-chalcopyrite grains; pyrrhotite-sphalerite-chalcopyrite inclusions in coarse-crystalline pyrite; anhedral and reniform chalcopyrite; specular and globular hematite, $\mathrm{HgS}$ phase in authigenic chalcopyrite and pyrite; quartz. Seafloor oxidation of sulfide 
breccias produced covellite after chalcopyrite and bornite, as well as jarosite and Fe-oxyhydroxides after pyrite and marcasite.

Diagenetic processes within the sulfide breccias also resulted in redistribution (i.e., evolution) of trace elements, which is evident from geochemical differences between primary hydrothermal and authigenic sulfides. The early diagenetic ovoid fine-crystalline pyrite is enriched in most trace elements relative to late diagenetic coarse-crystalline pyrite, similar to pyrite varieties from fine-clastic sedimentary rocks associated with Uralian VHMS deposits. Authigenic chalcopyrite and coarse-crystalline pyrite are depleted in most trace elements. The early diagenetic pore fluids circulated within clastic sediments were enriched in trace elements relative to late diagenetic fluids but were depleted in trace elements relative to hydrothermal fluids as well. Depletion of authigenic minerals in trace elements reflecting a depletion of pore diagenetic fluids in trace elements is also typical of fossil VHMS deposits.

The authigenic pyrite nodules of sulfide breccias from the Semenov-3 hydrothermal field and fossil VHMS deposits are similar in morphology and exhibit (i) a central porous domain with inclusions of sulfide and rock-forming minerals, (ii) an intermediate crystalline zone and (iii) a fine crystalline rim. In both fossil and present-day examples, the pyrite nodules show a compositional differentiation between the zones. These features point to a common diagenetic process, which occurred in Cenozoic and Paleozoic sediments composed of clasts of variable size, from coarse-clastic breccias to fine-clastic sediments. The composition of the associated sedimentary rocks and of the massive sulfide clasts, as well as their size, is responsible for the formation of specific authigenic mineral assemblages. The composition of authigenic pyrite nodules may be a proxy for the composition of the massive sulfide bodies.

Trace elements of sulfide breccias from the Semenov-3 hydrothermal field are characterized by different modes of occurrence: lattice-bound Se is hosted in pyrite and chalcopyrite; $\mathrm{Tl}$ is probably related to nanoinclusions of galena and sphalerite; $\mathrm{Au}$ is preferentially associated with nanoinclusions of galena; As in pyrite is lattice-bound, whereas in chalcopyrite it can also be related to tiny inclusions of tetrahedrite-tennantite; $\mathrm{Cd}$ in pyrite is hosted in sphalerite inclusions and forms its own mineral in chalcopyrite; correlation of $\mathrm{Co}$ and $\mathrm{Ni}$ with $\mathrm{Cu}$ and other trace elements suggests that they are hosted in chalcopyrite, even when this mineral is included in pyrite. These data should be taken into consideration during the economic evaluation and potential processing of similar massive sulfides. The finding of $\mathrm{Hg}$-bearing phase in sulfide breccias from the Semenov-3 hydrothermal field opens a problem of possible environmental hazardousness of similar eroded pyrite-rich ores and primary massive sulfides.

Supplementary Materials: The following are available online at http:/ /www.mdpi.com/2075-163X/8/8/321/s1, Table S1: LA-ICP-MS analyses and correlation matrices of sulfides from the Semenov-3 sulfide breccias.

Author Contributions: I.M., sampling and study of massive sulfides, interpretation of the results, writing of paper; V.V.M., LA-ICP-MS analysis, interpretation of the results; N.P.S., study of massive sulfides, interpretation of the results; P.N., microprobe analyses, interpretation of the results, language improvement; S.M., processing of LA-ICP-MS analyses; V.B. and I.R., providing samples and primary data on the hydrothermal field; L.D. and R.L., LA-ICP-MS analysis of sulfides; D.A., LA-ICP-MS mapping; V.K., electron microscopic studies; L.T., microprobe analyses, interpretation of the results.

Funding: This research was supported by State Contract number AAAA-A16-116021010244-0. The LA-ICP-MS mapping of the pyrite nodule was funded by the Russian Foundation for Basic Research, grant number 17-05-00854. P.N. and L.T. acknowledges financial support by MIUR ex60\% and DOR.

Acknowledgments: I.M. thanks staff of Polar Marine Geosurvey Expedition (St-Petersburg, Russia) for the possibility of participation in the 30th cruise of $R / V$ Professor Logatchev and massive sulfide sampling, Elena V. Belogub (IMin UB RAS) for consultations, and D. Kiseleva (IGG UB RAS, Yekaterinburg) for ICP-MS analyses. The authors are grateful to two anonymous reviewers and an Academic Editor for their detailed comments, which helped us to greatly improve our manuscript.

Conflicts of Interest: The authors declare no conflict of interest. 


\section{References}

1. Butler, I.B.; Nesbitt, R.V. Trace element distribution in the chalcopyrite wall of a black smoker chimney: Insights from laser ablation inductively coupled plasma mass spectrometry (LA-ICP-MS). Earth Planet. Sci. Lett. 1999, 167, 335-345. [CrossRef]

2. Maslennikov, V.V.; Maslennikova, S.P.; Large, R.R.; Danyushevsky, L.V. Study of trace element zonation in vent chimneys from the Silurian Yaman-Kasy volcanic-hosted massive sulfide deposit (Southern Urals, Russia) using laser ablation-inductively coupled plasma mass spectrometry (LA-ICP-MS). Econ. Geol. 2009, 104, 1111-1141. [CrossRef]

3. Maslennikov, V.V.; Maslennikova, S.P.; Large, R.; Danyushevsky, L.; Herrington, R.J.; Ayupova, N.R.; dZaykov, V.V.; Lein, A.Y.; Tseluyko, A.S.; Melekestseva, I.Y.; et al. Chimneys in Paleozoic massive sulfide mounds of the Urals VMS deposits: Mineral and trace element comparison with modern black, grey, white and clear smokers. Ore Geol. Rev. 2017, 85, 64-106. [CrossRef]

4. Melekestseva, I.Y.; Tret'yakov, G.A.; Nimis, P.; Yuminov, A.M.; Maslennikov, V.V.; Maslennikova, S.P.; Kotlyarov, V.A.; Beltenev, V.E.; Danyushevsky, L.V.; Large, R. Barite-rich massive sulfides from the Semenov-1 hydrothermal field (Mid-Atlantic Ridge, $13^{\circ} 30.87^{\prime} \mathrm{N}$ ): Evidence for phase separation and magmatic input. Mar. Geol. 2014, 349, 37-54. [CrossRef]

5. Melekestseva, I.Y.; Maslennikov, V.V.; Maslennikova, S.P.; Danyushevsky, L.; Large, R. Covellite from Semenov-2 hydrothermal field ( $13^{\circ} 31.13^{\prime}$ N, Mid-Atlantic Ridge): Enrichment in trace elements according to LA-ICP-MS analysis. Dokl. Earth Sci. 2017, 473, 291-295. [CrossRef]

6. Melekestseva, I.Y.; Maslennikov, V.V.; Tret'yakov, G.A.; Nimis, P.; Beltenev, V.E.; Rozhdestvenskaya, I.I.; Maslennikova, S.P.; Belogub, E.V.; Danyushevsky, L.; Large, R.; et al. Gold- and silver-rich massive sulfides from the Semenov-2 hydrothermal field, $13^{\circ} 31.13^{\prime} \mathrm{N}$, Mid-Atlantic Ridge: A case of magmatic contribution? Econ. Geol. 2017, 112, 741-773. [CrossRef]

7. Wohlgemuth-Ueberwasser, C.C.; Viljonen, F.; Petersen, S.; Vrster, C. Distribution and solubility limits of trace elements in hydrothermal black smoker sulfides: An in-situ LA-ICP-MS study. Geochim. Cosmochim. Acta 2015, 159, 16-41. [CrossRef]

8. Keith, M.; Häckel, F.; Haase, K.M.; Schwarz-Schampera, U.; Klemd, R. Trace element systematics of pyrite from submarine hydrothermal vents. Ore Geol. Rev. 2016, 72, 728-745. [CrossRef]

9. Fallon, E.K.; Petersen, S.; Brooker, R.A.; Scott, T.B. Oxidative dissolution of hydrothermal mixed-sulphide ore: An assessment of current knowledge in relation to seafloor massive sulphide mining. Ore Geol. Rev. 2017, 86, 309-337. [CrossRef]

10. Wang, Y.; Han, X.; Petersen, S.; Frische, M.; Qiu, Z.; Li, H.; Wu, Z.; Cui, R. Mineralogy and trace element geochemistry of sulfide minerals from the Wocan Hydrothermal Field on the slow-spreading Carlsberg Ridge, Indian Ocean. Ore Geol. Rev. 2017, 84, 1-19. [CrossRef]

11. Goodfellow, W.D.; Franklin, J.M. Geology, mineralogy, and chemistry of sediment-hosted clastic massive sulfides in shallow cores, Middle Valley, Northern Juan de Fuca Ridge. Econ. Geol. 1993, 88, 2037-2068. [CrossRef]

12. Ohmoto, H. Formation of volcanogenic massive sulfide deposits: The Kuroko perspective. Ore Geol. Rev. 1996, 16, 135-177. [CrossRef]

13. Prokin, V.A.; Buslaev, F.P. Massive copper-zinc sulphide deposits in the Urals. Ore Geol. Rev. 1998, 14, 1-69. [CrossRef]

14. Herrington, R.; Maslennikov, V.; Zaykov, V.; Seravkin, I.; Kosarev, A.; Buschmann, B.; Orgeval, J.-J.; Holland, N.; Tesalina, S.; Nimis, P.; et al. Classification of VMS deposits: Lesson from the South Uralides. Ore Geol. Rev. 2005, 27, 203-237. [CrossRef]

15. Maslennikov, V.V. Morphogenetic analysis of massive sulfide bodies as a reflection of volcanic regimes. Litosfera 2012, 5, 96-113. (In Russian)

16. Tornos, F.; Peter, J.M.; Allen, R.; Conde, C. Controls on the siting and style of volcanogenic massive sulphide deposits. Ore Geol. Rev. 2015, 68, 142-163. [CrossRef]

17. Fairbridge, R.W. Phases of diagenesis and authigenesis. In Diagenesis in Sediments; Larsen, G., Chilingar, G.V., Eds.; Elsevier: Amsterdam, The Netherlands, 1967; pp. 19-89. [CrossRef] 
18. Maslennikov, V.V.; Ayupova, N.R.; Artemyev, D.A.; Tseluyko, A.S. Microtopochemistry of marcasite-pyrite nodule in illite-hematite gossanites of the Lahanos massive sulfide deposit (Pontides, Turkey) by LA-ICP-MS data. Mineralogiya 2017, 3, 48-70. (In Russian)

19. Safina, N.P.; Maslennikov, V.V.; Artemyev, D.A.; Arkhireeva, N.S. Microtopochemistry and geochemical features of a pyrite nodule of carbonaceous siltstones of the Saf'yanovka massive sulfide deposit (Central Urals). Mineralogiya 2017, 3, 22-36. (In Russian)

20. Hannington, M.; Jamieson, J.; Monecke, T.; Petersen, S.; Beaulieu, S. The abundance of seafloor massive sulfide deposits. Geology 2011, 39, 1155-1158. [CrossRef]

21. Hein, J.R.; Mizell, K.; Koschinsky, A.; Conrad, T. Deep-ocean mineral deposits as a source of critical metals for high- and green-technology applications: Comparison with land-based deposits. Ore Geol. Rev. 2013, 51, 1-14. [CrossRef]

22. Monecke, T.; Petersen, S.; Hannington, M.D.; Grant, H.; Samson, I. The minor element endowment of modern sea-floor massive sulfides and comparison with deposits hosted in ancient volcanic successions. Econ. Geol. 2016, 18, 245-306.

23. Van Dover, C.L.; Arnaud-Haond, S.; Gianni, M.; Helmreich, S.; Huber, J.A.; Jaeckel, A.L.; Metaxas, A.; Pendleton, L.H.; Petersen, S.; Ramirez-Llodra, E.; et al. Scientific rationale and international obligations for protection of active hydrothermal vent ecosystems from deep-sea mining. Mar. Policy 2018, 90, 20-28. [CrossRef]

24. Nautilus Minerals. Available online: http://www.nautilusminerals.com/irm/content/png.aspx?RID=258 (accessed on 14 May 2018).

25. Nautilus Minerals. Available online: http://www.nautilusminerals.com/IRM/ShowCategory. aspx?CategoryId=311\&FilterStyle=B\&archive $=$ true $\&$ masterpage $=31 \& y e a r=2014 \& R I D=291$ (accessed on 14 May 2018).

26. Marchig, V.; Blum, N.; Roonwal, G. Massive sulfide chimneys from the East Pacific Rise at $7^{\circ} 24^{\prime} \mathrm{S}$ and 16²3' S. Mar. Georesour. Geotechnol. 1997, 15, 49-66. [CrossRef]

27. Embley, R.W.; Jonasson, I.R.; Perfit, M.R.; Franklin, J.M.; Tivey, M.A.; Malahoff, A.; Smith, M.F.; Francis, T.J.G. Submersible investigation of an extinct hydrothermal system on the Galapagos Ridge; sulfide mounds, stockwork zone, and differentiated lavas. Can. Mineral. 1988, 26, 517-539.

28. Fouquet, Y.; Wafik, A.; Cambon, P.; Mevel, C.; Meyer, G.; Gente, P. Tectonic setting and mineralogical and geochemical zonation in the Snake Pit sulfide deposit (Mid-Atlantic Ridge at $23^{\circ} \mathrm{N}$ ). Econ. Geol. 1993, 88, 2018-2036. [CrossRef]

29. Rona, P.A.; Hannington, M.D.; Raman, C.V.; Thompson, G.; Tivey, M.K.; Humphris, S.E.; Lalou, C.; Petersen, S. Active and relict sea-floor hydrothermal mineralization at the TAG hydrothermal field, Mid-Atlantic Ridge. Econ. Geol. 1993, 88, 1989-2117. [CrossRef]

30. Duckworth, R.C.; Knott, R.; Fallick, A.E.; Ricard, D.; Murton, B.J.; Van Dover, C. Mineralogy and sulphur isotope geochemistry of the Broken Spur sulphides, $29^{\circ} \mathrm{N}$, Mid-Atlantic Ridge. In Hydrothermal Vents and Processes; Parson, L.M., Walker, C.L., Dixon, D.R., Eds.; Geological Society London Special Publication: London, UK, 1995; pp. 175-190. [CrossRef]

31. Petersen, S.; Herzig, P.M.; Hannington, M.D. Third dimension of a presently forming VMS deposit: TAG hydrothermal field, Mid-Atlantic Ridge, $26^{\circ}$ N. Miner. Depos. 2000, 35, 233-259. [CrossRef]

32. Bogdanov, Y.A.; Lein, A.Y.; Sagalevich, A.M.; Dorofeev, S.A.; Ul'yanova, N.V. Hydrothermal sulfide deposits of the Lucky Strike vent field, Mid-Atlantic Ridge. Geochem. Int. 2006, 44, 403-418. [CrossRef]

33. Bogdanov, Y.A.; Lein, A.Y.; Maslennikov, V.V.; Li, S.; Ul'yanov, A.A. Mineralogical-geochemical features of sulfide ores from the Broken Spur hydrothermal vent field. Oceanology 2008, 48, 679-700. [CrossRef]

34. Tao, C.; Li, H.; Huang, W.; Han, X.; Wu, G.; Su, X.; Zhou, N.; Lin, J.; He, Y.; Zhou, J. Mineralogical and geochemical features of sulfide chimneys from the $49^{\circ} 39^{\prime} \mathrm{E}$ hydrothermal field on the Southwest Indian Ridge and their geological inferences. Chin. Sci. Bull. 2011, 56, 2828-2838. [CrossRef]

35. Cherkashov, G.A.; Ivanov, V.N.; Beltenev, V.E.; Lazareva, L.I.; Rozhdestvenskaya, I.I.; Samovarov, M.L.; Poroshina, I.M.; Sergeev, M.B.; Stepanova, T.V.; Dobretsova, I.G.; et al. Sulfide ores of the northern equatorial part of the Mid-Atlantic Ridge. Oceanology 2013, 53, 680-693. [CrossRef] 
36. Wang, Y.; Han, X.; Petersen, S.; Jin, X.; Qiu, Z.; Zhu, J. Mineralogy and geochemistry of hydrothermal precipitates from Kairei hydrothermal field, Central Indian Ridge. Mar. Geol. 2014, 354, 69-80. [CrossRef]

37. Wang, S.; Li, H.; Zhai, S.; Yu, Z.; Cai, Z. Geochemical features of sulfides from the Deyin-1 hydrothermal field at the Southern Mid-Atlantic Ridge near $15^{\circ}$ S. J. Oceanol. Univ. China 2017, 16, 1043-1054. [CrossRef]

38. Beltenev, V.; Ivanov, V.; Rozhdestvenskaya, I.; Cherkashov, G.; Stepanova, T.; Shilov, V.; Pertsev, A.; Davydov, M.; Egorov, I.; Melekestseva, I.; et al. A new hydrothermal field at $13^{\circ} 30^{\prime} \mathrm{N}$ on the Mid-Atlantic Ridge. InterRidge News 2007, 16, 9-10.

39. MacLeod, C.J.; Searle, R.C.; Murton, B.J.; Casey, J.F.; Mallows, C.; Unsworth, S.C.; Achenbach, K.L.; Harris, M. Life cycle of oceanic core complexes. Earth Planet. Sci. Lett. 2009, 287, 333-344. [CrossRef]

40. Beltenev, V.; Ivanov, V.; Rozhdestvenskaya, I.; Cherkashov, G.; Stepanova, T.; Shilov, V.; Davydov, M.; Laiba, A.; Kaylio, V.; Narkevsky, E.; et al. New data about hydrothermal fields on the Mid-Atlantic Ridge between $11^{\circ}-14^{\circ} \mathrm{N}$ : 32nd cruise of R/V Professor Logatchev. InterRidge News 2009, 18, 14-18.

41. Pertsev, A.N.; Bortnikov, N.S.; Vlasov, E.A.; Beltenev, V.E.; Dobretsova, I.G.; Ageeva, O.A. Recent sulfide deposits of the Semenov ore region (Mid-Atlantic Ridge, $13^{\circ} 30^{\prime} \mathrm{N}$ ): Types of associated rocks of the oceanic core complex and their hydrothermal alteration. Geol. Ore Depos. 2012, 54, 334-346. [CrossRef]

42. Kuznetsov, V.; Maksimov, F.; Zheleznov, A.; Cherkashov, G.; Bel'tenev, V.; Lazareva, L. ${ }^{230}$ Th/U chronology of ore formation within the Semyenov hydrothermal district $\left(13^{\circ} 31^{\prime} \mathrm{N}\right)$ at the Mid-AtlanticRidge. Geochronometria 2011, 38, 72-76. [CrossRef]

43. Longerich, H.P.; Jackson, S.E.; Gunte, D. Laser ablation inductively coupled plasma mass spectrometric transient signal data acquisition and analyte concentration calculation. J. Anal. At. Spectrom. 1996, 11, 899-904. [CrossRef]

44. Danyushevsky, L.V.; Robinson, R.; Gilbert, S.; Norman, M.; Large, R.; McGoldrick, P.; Shelley, J.M.G. Routine quantitative multielement analysis of sulfide minerals by laser ablation ICP-MS: Standard development and consideration of matrix effects. Geochem. Explor. Environ. Anal. 2011, 11, 51-60. [CrossRef]

45. Wilson, S.A.; Ridley, W.I.; Koenig, A.E. Development of sulphide calibration standards for the laser ablation inductively-coupled plasma mass spectrometry technique. J. Anal. At. Spectrom. 2002, 17, 406-409. [CrossRef]

46. Safina, N.P.; Melekestseva, I.Y.; Nimis, P.; Ankusheva, N.N.; Yuminov, A.M.; Kotlyarov, V.A.; Sadykov, S.A. Barite from the Saf'yanovka VMS deposit (Central Urals) and Semenov-1 and Semenov-3 hydrothermal sulfide fields (Mid-Atlantic Ridge): A comparative analysis of formation conditions. Miner. Depos. 2016, 54, 491-507. [CrossRef]

47. Maslennikov, V.V.; Zaykov, V.V. Massive Sulfide Paleohydrothermal Fields of Marginal Oceanic Structures of the Urals: Classification, Ore Facies, Evolution Model; IMin UB RAS: Miass, Russia, 1998; 92p. (In Russian)

48. Maslennikov, V.V. Sedimentogenesis, Halmyrolysis and Ecology of Massive Sulfide-Bearing Paleohydrothermal Fields; Geotur: Miass, Russia, 1999; 348p. (In Russian)

49. Maslennikov, V.V.; Maslennikova, S.P.; Large, R.R.; Danyushevsky, L.V.; Herrington, R.J.; Stanley, C.J. Tellurium-bearing minerals in zoned sulfide chimneys from $\mathrm{Cu}-\mathrm{Zn}$ massive sulfide deposits of the Urals, Russia. Mineral. Petrol. 2013, 107, 67-99. [CrossRef]

50. Love, L.G. Early diagenetic iron sulphide in Recent sediments of the Wash (England). Sedimentology 1967, 9, 327-352. [CrossRef]

51. Love, L.G.; Amstutz, G.C. Review of microscopic pyrite from the Devonian Chattanooga shale and Rammelsberg Banderz. Fortschr. Mineral. 1966, 43, 273-309.

52. Posfai, M.; Dunin-Borkowski, R.E. Sulfides in biosystems. Rev. Mineral. Geochem. 2006, 61, 679-714. [CrossRef]

53. Safina, N.P.; Maslennikov, V.V. Sequence of mineral formation in clastic ores of the Saf'yanovka volcanic-hosted copper massive sulfide deposit, the Central Urals. Geol. Ore Depos. 2009, 51, 633-643. [CrossRef]

54. Safina, N.P.; Maslennikov, V.V. Ore Clastic Sediments from Yaman-Kasy and Saf'yanovka Massive Sulfide Deposits, the Urals; IMin UB RAS: Miass, Russia, 2009; 260p. (In Russian)

55. Binns, R.A.; Scott, S.D. Actively forming polymetallic sulfide deposits associated with felsic volcanic rocks in the eastern Manus back-arc basin, Papua New Guinea. Econ. Geol. 1993, 88, 2226-2236. [CrossRef]

56. De Ronde, C.E.J.; Massoth, G.J.; Butterfield, D.A.; Christenson, B.W.; Ishibashi, J.; Ditchburn, R.G.; Hannington, M.D.; Brathwaite, R.L.; Lupton, J.E.; Kamenetsky, V.S.; et al. Submarine hydrothermal activity 
and gold-rich mineralization at Brothers Volcano, Kermadec Arc, New Zealand. Miner. Depos. 2011, 46, 541-584. [CrossRef]

57. Berkenbosch, H.A.; de Ronde, C.E.J.; Gemmel, J.B.; McNeil, A.W.; Goemann, K. Mineralogy and formation of black smoker chimneys from Brothers submarine volcano, Kermadec arc. Econ. Geol. 2012, 107, 1613-1633. [CrossRef]

58. $\quad$ Large, R.R.; Danyushevsky, L.; Hollit, C.; Maslennikov, V.; Meffre, S.; Gilbert, S.; Bull, S.; Scott, R.; Emsbo, P.; Thomas, H.; et al. Gold and trace element zonation in pyrite using a laser imaging technique: Implications for the timing of gold in orogenic and Carlin-style sediment-hosted deposits. Econ. Geol. 2009, 104, 635-668. [CrossRef]

59. Deditius, A.P.; Utsunomiya, S.; Reich, M.; Kesler, S.E.; Ewing, R.C.; Hough, R.; Walshe, J. Trace metal nanoparticles in pyrite. Ore Geol. Rev. 2011, 42, 32-46. [CrossRef]

60. Huston, D.L.; Sie, S.H.; Suter, G.F.; Cooke, D.R.; Both, R.A.Q. Trace elements in sulfide minerals from eastern Australian volcanic hosted massive sulfide deposits. Part I. Proton microprobe analyses of pyrite, chalcopyrite, and sphalerite. Part II. Selenium levels in pyrite comparison with $\delta^{34} \mathrm{~S}$ values and implication for the source of sulfur in volcanogenic hydrothermal systems. Econ. Geol. 1995, 90, 1167-1196. [CrossRef]

61. Fouquet, Y.; Cambon, P.; Etoubleau, J.; Charlou, J.-L.; Ondréas, H.; Barriga, F.J.A.S.; Cherkashov, G.; Semkova, T.; Poroshina, I.; Bohn, M.; et al. Geodiversity of hydrothermal processes along the Mid-Atlantic Ridge and ultramafic-hosted mineralization: A new type of oceanic $\mathrm{Cu}-\mathrm{Zn}-\mathrm{Co}-\mathrm{Au}$ volcanogenic massive sulfide deposits. In Diversity of Hydrothermal Systems on Slow Spreading Ocean Ridges; Rona, P.A., Devey, C.W., Dyment, J., Murton, B.J., Eds.; American Geophysical Union: Washington, DC, USA, 2010; pp. 321-368.

62. Hannington, M.D.; Bleeker, W.; Kjarsgaard, I. Sulfide mineralogy, geochemistry and ore genesis of the Kidd Creek deposit: Part I. North, Central and South orebodies. In The Giant Kidd Creek Volcanogenic Massive Sulfide Deposit, Western Abitibi Subprovince, Canada; Economic Geology Monograph; Society of Economic Geologists: Littleton, CO, USA, 1999; Volume 10, pp. 163-224.

63. Halbach, P.E.; Tunnicliffe, V.; Hein, J.R. Energy and Mass Transfer in Marine Hydrothermal Systems; Dahlem University Press: Berlin, Germany, 2003; 365p.

64. George, L.; Cook, N.J.; Ciobanu, C.L.; Wade, B.P. Trace and minor elements in galena: A reconnaissance LA-ICP-MS study. Am. Mineral. 2015, 100, 548-569. [CrossRef]

65. Genna, D.; Gaboury, D. Deciphering the hydrothermal evolution of a VMS system by LA-ICP-MS using trace elements in pyrite: An example from the Bracemac-McLeod deposits, Aditibi, Canada, and implication for exploration. Econ. Geol. 2015, 110, 2087-2108. [CrossRef]

66. Maslennikov, V.V.; Ayupova, N.R.; Herrington, R.J.; Danyushevskiy, L.V.; Large, R.R. Ferruginous and manganiferous haloes around massive sulphide deposits of the Urals. Ore Geol. Rev. 2012, 47, 5-41. [CrossRef]

67. Tseluyko, A.S.; Maslennikov, V.V.; Artemyev, D.A. Microtopochemistry of pyrite nodules of siliceous siltstones from the Yubileynoe massive sulfide deposit (South Urals): LA-ICP-MS data. Litosfera 2018. in press (In Russian)

68. Safina, N.P.; Maslennikov, V.V. Lithological-mineralogical zonality of sulfide cyclothems in the Yaman-Kasy and Saf'yanovka massive sulfide deposits (Urals). Dokl. Earth Sci. 2008, 419, 432-434. [CrossRef]

69. Fallon, E.K.; Niehorster, E.; Brooker, R.A.; Scott, T.B. Experimental leaching of massive sulphide from TAG active hydrothermal mound and implications for seafloor mining. Mar. Pollut. Bull. 2018, 126, 501-515. [CrossRef] [PubMed]

70. Berlin, M.; Zalups, R.K.; Fowler, B.A. Mercury. In Handbook on the Toxicology of Metals, 3rd ed.; Nordberg, G.F., Fowler, B.A., Nordberg, M., Friberg, L.T., Eds.; Elsevier: Amsterdam, The Netherlands, 2007; pp. 675-729.

71. Halbach, P.; Praceius, B.; Marten, A. Geology and mineralogy of massive sulphide ores from the Central Okinawa Trough, Japan. Econ. Geol. 1993, 88, 2210-2225. [CrossRef]

72. Lodenius, M. Mercury in terrestrial ecosystems: A review. In Mercury Pollution: Integration and Synthesis; Watras, C.J., Huckabee, J.W., Eds.; Lewis Publishers: Boca Raton, FL, USA, 1994; pp. 343-354.

73. Petersen, S.; Herzig, P.M.; Schwarz-Schampera, U.; Hannington, M.D.; Jonasson, I.R. Hydrothermal precipitates associated with bimodal volcanism in the Central Bransfield Strait, Antarctica. Miner. Depos. 2004, 39, 358-379. [CrossRef] 
74. Maslennikov, V.V.; Ayupova, N.R.; Maslennikova, S.P.; Tret'yakov, G.A.; Melekestseva, I.Y.; Safina, N.P.; Belogub, E.V.; Large, R.R.; Danyushevsky, L.V.; Tseluyko, A.S.; et al. Toxic Elements in Massive Sulfide-Forming Systems; UB RAS: Yekaterinburg, Russia, 2014; 340p. (In Russian)

75. Kowalczuk, P.B.; Manaig, D.O.; Drivenes, K.; Snook, B.; Aasly, K.; Kleiv, R.A. Galvanic leaching of seafloor massive sulphides using $\mathrm{MnO}_{2}$ in $\mathrm{H}_{2} \mathrm{SO}_{4}-\mathrm{NaCl}$ media. Minerals 2018, 8, 235. [CrossRef] 